\title{
CD122 signaling in CD8+ memory T cells drives costimulation-independent rejection
}

\author{
David V. Mathews, ${ }^{1}$ Ying Dong, ${ }^{1}$ Laura B. Higginbotham, ${ }^{1}$ Steven C. Kim, ${ }^{1}$ Cynthia P. Breeden,, ${ }^{1}$ Elizabeth A. Stobert, ${ }^{2}$ \\ Joseph Jenkins, ${ }^{2}$ J. Yun Tso, ${ }^{3}$ Christian P. Larsen, ${ }^{1,2}$ and Andrew B. Adams ${ }^{1,2}$ \\ 'Emory Transplant Center, Emory University, Atlanta, Georgia, USA. ${ }^{2}$ Yerkes National Primate Center, Atlanta, Georgia, USA. ${ }^{3}$ JN Biosciences, Mountain View, California, USA.
}

\begin{abstract}
Interrupting T cell costimulatory signals as a strategy to control undesired immune responses, such as occur in autoimmunity or transplantation, has the potential to alleviate many of the unwanted side effects associated with current immunosuppressive therapies. Belatacept, a high-affinity version of CTLA4-Ig that blocks ligand ligation to CD28, has been approved for use in kidney transplant recipients. Despite the long-term benefits associated with its use, such as improved renal function and lower cardiovascular risk, a subset of patients treated with belatacept experience elevated rates of acute T cell-mediated rejection, tempering enthusiasm for its use. Here we demonstrate that costimulation-independent $T$ cell alloreactivity relies on signaling through CD122, the shared IL-2 and IL-15 receptor $\beta$-chain. Combined costimulatory and CD122 blockade improved survival of transplanted tissue in mice and nonhuman primates by controlling proliferation and effector function of $\mathrm{CD8}^{+} \mathrm{T}$ cells. The high-affinity IL-2 receptor was dispensable for memory $\mathrm{CD8}^{+} \mathrm{T}$ cell responses, whereas signaling through CD122 as a component of the high-affinity IL-15 receptor was critical for costimulation-independent memory CD8 ${ }^{+}$ cell recall, distinguishing specific roles for IL-2 and IL-15 in T cell activation. These studies outline a novel approach for clinical optimization of costimulatory blockade strategies in transplantation by targeting CD122.
\end{abstract}

\section{Introduction}

Blockade of key $\mathrm{T}$ cell costimulatory pathways represents a more targeted strategy to prevent unwanted immune responses such as rejection in transplant recipients. Recently, belatacept, a high-affinity variant of the CTLA4-Ig fusion protein, became the first approved alternative to conventional nonspecific immunosuppression for kidney transplant recipients $(1,2)$. Compared with patients receiving cyclosporine, transplant patients treated with belatacept enjoyed superior function of their transplanted kidney with fewer off-target toxicities and a $43 \%$ risk reduction of death or graft loss in a 7-year follow-up (3-5). Despite these improvements, a significant subset of patients experienced elevated rates and grades of acute allograft rejection during belatacept therapy $(6,7)$. Belatacept specifically interrupts $\mathrm{T}$ cell costimulatory signals mediated by CD28-CD80/CD86 interactions. Memory $\mathrm{CD}^{+} \mathrm{T}$ cells are capable of mounting alloimmune responses despite blockade of CD28 and CD154 costimulatory molecules $(8-11)$. We recently demonstrated that a critical threshold of $\mathrm{T}$ cell memory can effectively predict belatacept resistance in patients and nonhuman primates (NHPs) and that belatacept-resistant rejection is uniquely characterized by allograft infiltrate that is more fully differentiated, with a unique proinflammatory cytokine signature $(12,13)$. There are subsets of memory CD8 ${ }^{+} \mathrm{T}$ cells in humans and NHPs that lack CD28 expression altogether and rely on alternative signals for

Conflict of interest: ABA has received research funding and consulting fees from BMS. JYT is an employee and managing partner of JN Biosciences LLC.

Submitted: July 13, 2017; Accepted: July 31, 2018

Reference information: J Clin Invest. 2018;128(10):4557-4572.

https://doi.org/10.1172/JCI95914 activation $(14,15)$. One such signal is provided by the shared IL-2 and IL-15 cytokine signaling complex.

IL-2 and IL-15 signals depend on the assembly of high-affinity heterotrimeric receptors which share a $\beta$-chain (CD122) and common $\gamma$-chain $\left(\gamma_{c}\right)(16)$. The unique contributions of these cytokines to host protection and alloimmunity, while described, are not fully elucidated. Interestingly, IL-2/IL-2R $\alpha$ knockout animals exhibit autoimmunity, whereas IL-15/IL-15R $\alpha$ knockout animals have diminished CD8, IELS, NK, and NKT cells, suggesting that these 2 cytokines have unique biological roles despite a shared signaling complex (17-20). Blocking the shared IL-2/IL-15R $\beta$ has ameliorated disease in a murine model of IL-15-dependent autoimmunity (21). Additionally, we know that IL-15 signaling is critical for memory $\mathrm{CD}^{+} \mathrm{T}$ cell homeostasis and survival (22-24). Exogenous IL-15 has been shown to induce expansion of memory CD8 ${ }^{+} \mathrm{T}$ cells in rhesus monkeys (25). Inflammation may drive IL-15 production, leading to enhanced trafficking and proliferation of memory T cells following viral infection, but it is unclear what role IL-15 signaling has in transplant rejection, including its role in costimulation-independent $\mathrm{T}$ cell responses (26). We and others have demonstrated that IL-2 and IL-15 signaling induces the loss of CD28 while providing other activation signals $(27,28)$. Thus, signaling through the IL-2/IL-15 receptor complex may activate alloreactive T cells while making them increasingly resistant to belatacept due to loss of CD28. In support of this, recent studies by Traitanon et al demonstrate that IL-15 uniquely drives the proliferation of human alloreactive memory $\mathrm{CD} 8^{+} \mathrm{T}$ cells, despite costimulatory blockade (CoB) with CTLA4-Ig (29). Here we demonstrate that blockade of the shared IL-2 and IL-15 receptor $\beta$-chain, CD122, synergizes with $\mathrm{CoB}$ to abrogate both primary and memory $\mathrm{CD}^{+} \mathrm{T}$ cell responses to transplanted tissue and results in prolonged trans- 
A LCMV

Armstrong

$\therefore-$ infection

$\mathrm{C} 57 \mathrm{BL} / 6\left(\mathrm{H}^{\mathrm{b}}\right)$ Longitudinal

$C \longrightarrow \stackrel{\text { Longitudin }}{\text { analysis }}$

(1)

Splenic

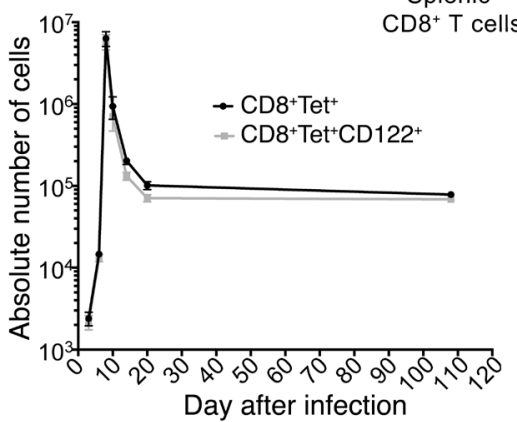

D
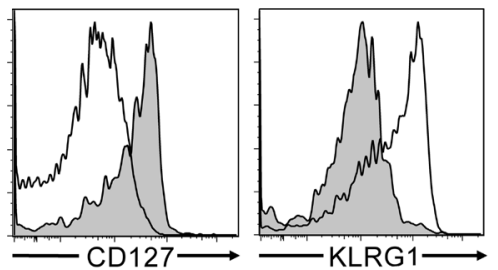

$\mathbf{F}$

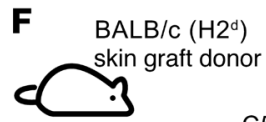

$\mathrm{C} 57 \mathrm{BL} / 6\left(\mathrm{H}^{\mathrm{b}}\right)$
Recipient
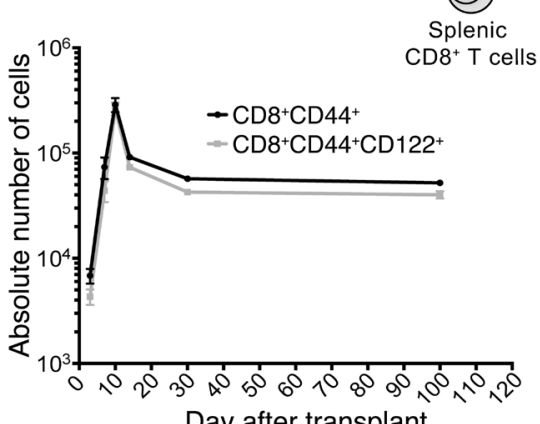

Day after transplant

I

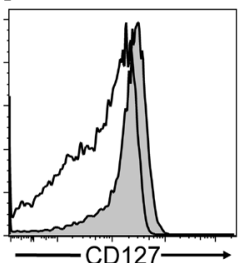

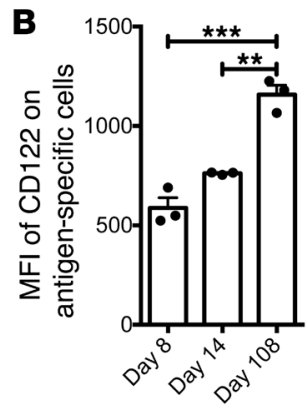
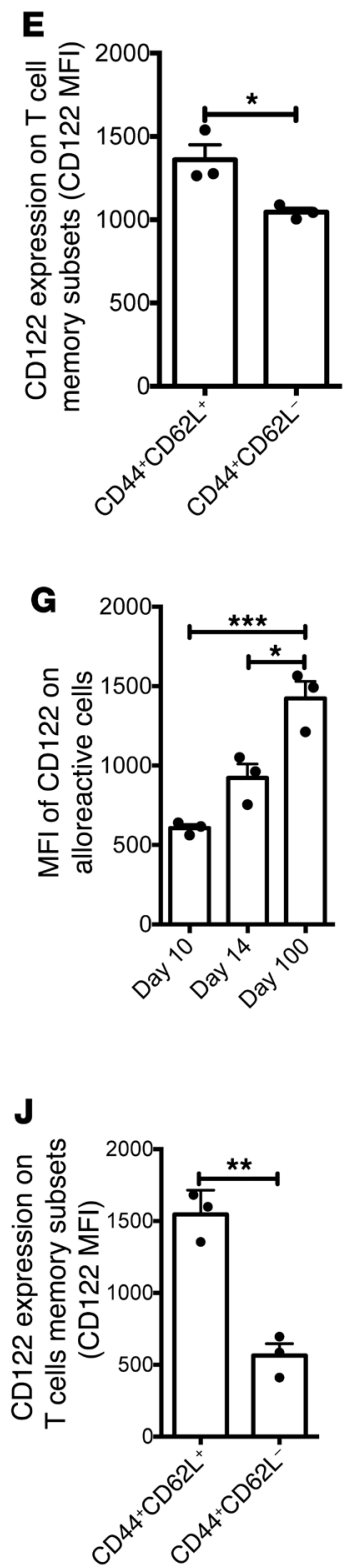

C
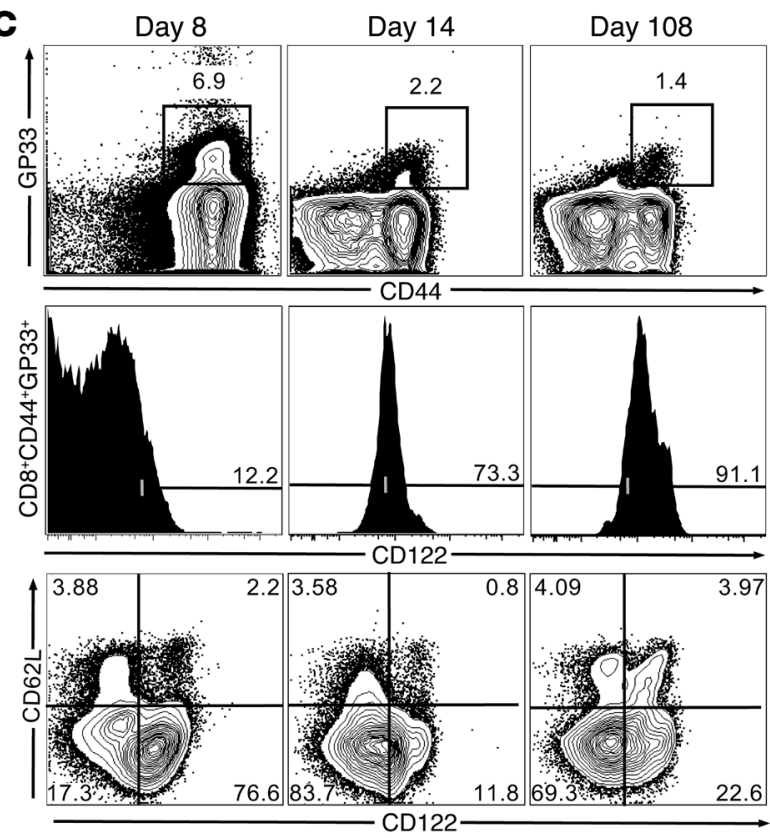

H
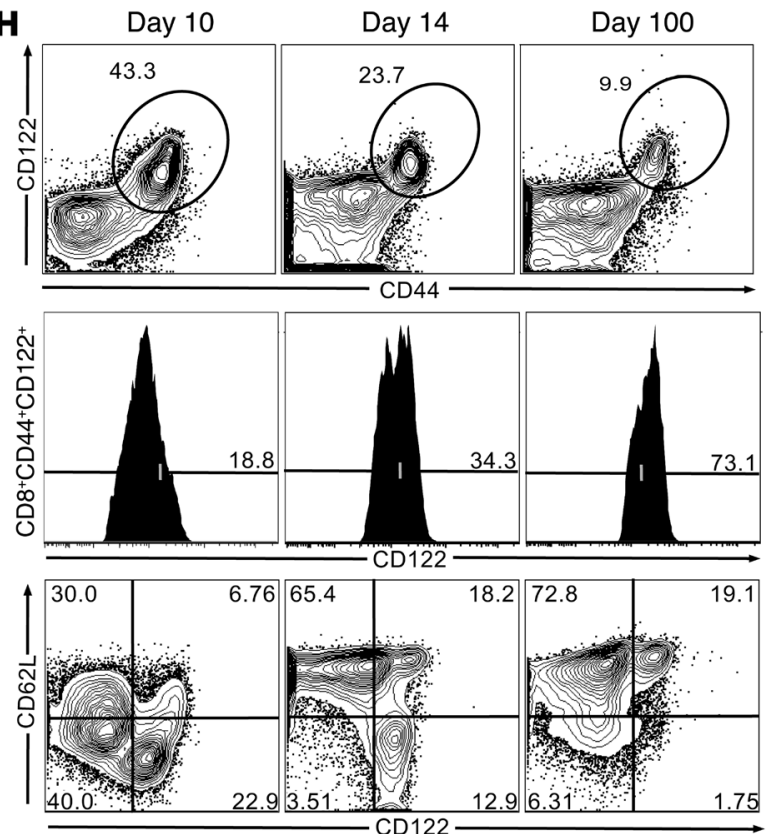
Figure 1. Kinetics of CD122 expression on CD8 T cells in acute viral infection and allograft rejection. (A) C57BL/6 mice were infected with LCMV Armstrong strain. The frequency and phenotype of antigen-specific (CD44+ ${ }^{+}$P33 tetramer ${ }^{+}$) splenic CD8 ${ }^{+} T$ cells were assessed longitudinally, and more than $95 \%$ of all antigen-specific T cells (black circles) expressed CD122 (gray squares). (B) The MFI of CD122 on antigen-specific T cells was highest at day 108 compared with day $8, P=0.0002$. (C) Representative FACS plot of data shown in $\mathbf{A}$ (top row) and $\mathbf{B}$ (middle row). Bottom row depicts changing phenotype of CD122+ cells after infection. (D) Representative histogram demonstrating that antigen-specific $T$ cells are phenotypically CD127/0 KLRG hi $^{\mathrm{h}}$ on day 8 after infection (unshaded) compared with a memory time point (day 108), when cells were CD127 ${ }^{\text {hi }} \mathrm{KLRG}^{10}$ (shaded). (E) CD122 is more highly expressed on antigen-specific $T_{C M}\left(C D 44^{+}{ }^{\left.C D 62 L^{+}\right)}\right.$ CD8 ${ }^{+} \mathrm{T}$ cells compared with $\mathrm{T}_{\mathrm{EM}}$ (CD44+CD62L-) CD8 ${ }^{+} \mathrm{T}$ cells $(P=0.0274)$. (F) C57BL/6 $(\mathrm{H} 2 \mathrm{~b})$ mice received $\mathrm{BALB} / \mathrm{C}(\mathrm{H} 2 \mathrm{~d})$ skin grafts and were assessed longitudinally, similar to $A$. The majority of alloreactive $C D 8^{+} C D 44^{+} T$ cells (black circles) expressed CD122 (gray squares). (C) CD122 MFI was highest 100 days after transplant $(P=0.0011)$. (H) Representative FACS plot of data shown in $\mathbf{F}$ (top row) and $\mathbf{G}$ (middle row). Bottom row depicts phenotypic changes after transplant. (I) CD122+ cells demonstrate similar CD127 and KLRG1 expression at the peak of rejection (unshaded) and memory (shaded) compared with infection (D). (J) Alloreactive CD8 ${ }^{+} T_{C M}$ cells express higher levels of CD122 compared with $\mathrm{T}_{\mathrm{EM}} \mathrm{CD}^{+} \mathrm{T}$ cells $(P=0.0016)$. $P$ values generated by 1-way ANOVA with Tukey's multiple comparisons test (B, G). Student's $t$ test, 2-tailed. Bars represent the mean \pm SEM of 3 mice per group $(E, J)$. All results, including FACS plots, represent 3 independent experiments ( $n=3$ mice/group). ${ }^{*} P<0.05$; ${ }^{* *} P<0.01$; ${ }^{* *} P<0.001$.

plant survival in mice and NHPs. Interestingly, blockade of the high-affinity IL-2 receptor failed to inhibit T cell recall and graft rejection, whereas blockade of CD122 controlled CD8 ${ }^{+}$memory $\mathrm{T}$ cells, suggesting recall responses uniquely require IL-15, but can dispense with IL-2. This data supports a role for IL-15 not only in memory $\mathrm{T}$ cell homeostasis but also in memory $\mathrm{T}$ cell activation, proliferation, and acquisition of effector function. In contrast, the high-affinity IL-2 receptor in combination with $\mathrm{CoB}$ is sufficient to prevent primary allo-specific $\mathrm{T}$ cell responses. CD122-directed therapy allows for blockade of 2 pathways involved in $\mathrm{T}$ cell activation, IL-2 and IL-15, which possess distinct functions as signal 3 cytokines in primary and recall responses, respectively.

We translated these findings into a preclinical, NHP renal transplant model where we characterized the expression of CD122 as a marker of antigen-experienced memory $\mathrm{CD}^{+} \mathrm{T}$ cells, and found that IL-15 augments effector function of T cells, more so than IL-2, across the spectrum of memory $\mathrm{T}$ cell differentiation. Belatacept-resistant allograft infiltrate was characterized by high expression of CD122, but not CD25. The addition of a novel humanized CD122 blocking antibody synergized with belatacept to abrogate alloreactivity in vitro and markedly prolong survival of NHP renal transplant recipients. These data offer a novel strategy for the optimization of $\mathrm{CoB}$ in transplantation and define a critical role for CD122 in both primary and secondary immune responses, as part of the IL-2 and IL-15 receptor systems, respectively. Our studies suggest that signaling through IL-2/IL-15R (CD122) directly contributes to costimulation independence. The translation of CD122-directed therapy for transplantation may be superior to currently approved therapies targeting CD25, which may also deplete regulatory T cells (30). Furthermore, CD122-directed therapy has the benefit of interrupting the IL-2 receptor and the IL-15 receptor, inhibiting both primary and secondary alloreactive
$\mathrm{T}$ cell responses. These data improve our understanding of the basic signaling requirements of $\mathrm{T}$ cells, and highlight the distinctive role of IL-15R in graft-specific memory responses.

\section{Results}

CD122 is highly expressed on antigen-specific memory $C D 8^{+} T$ cells. High levels of CD122 expression distinguish memory $\mathrm{CD}^{+} \mathrm{T}$ cells and NK cells (31). Consistent with previous reports, we observed elevated CD122 expression on nearly all activated $\left(\mathrm{CD} 44^{+}\right) \mathrm{CD}^{+}$ $\mathrm{T}$ cells following viral infection (32). In a well-described model of acute viral infection with the Armstrong strain of lymphocytic choriomeningitis virus (LCMV), we found CD122 to be expressed on more than $95 \%$ of viral antigen-specific cells tracked with GP33 tetramer (Figure 1A, corresponding FACS plot Figure 1C). Virus-specific $\mathrm{CD}^{+} \mathrm{T}$ cells not only maintained CD122 expression over time but the CD122 MFI increased as the population of antigen-specific $\mathrm{T}$ cells matured to a memory phenotype (Figure 1B, corresponding FACS plot Figure 1C). We observed that IL-2/ IL-15R $\beta$ (CD122) is expressed on both short-lived effector cells at the peak of response to infection (KLRG $1^{\text {hi }} \mathrm{CD} 127^{\text {lo }} \mathrm{CD} 8^{+} \mathrm{T}$ cells) as well as memory $\mathrm{T}$ cells (KLRG $1^{\text {lo }} \mathrm{CD} 127^{\text {hi }} \mathrm{CD} 8^{+} \mathrm{T}$ cells, Figure 1D). Antigen-specific central memory $\mathrm{CD} 44^{+} \mathrm{CD} 62 \mathrm{~L}^{+} \mathrm{CD} 8^{+} \mathrm{T}$ cells exhibited the highest expression of CD122 when compared with effector memory CD $44^{+} \mathrm{CD} 62 \mathrm{~L}^{-} \mathrm{CD} 8^{+} \mathrm{T}$ cells at 3 months after infection (Figure 1E, corresponding FACS plot Figure 1C). Phenotypically, CD122 expression on antigen-specific cells suggests an important role for CD122 during acute responses and in memory.

Virus-specific and alloreactive $C D 8^{+} T$ cells demonstrate similar expression of $C D 122$. We translated these findings to a model of transplantation to characterize CD122 expression on alloreactive $\mathrm{CD}^{+} \mathrm{T}$ cells during a primary challenge with an allograft. We characterized CD122 expression on alloreactive CD $44^{+} \mathrm{CD} 8^{+}$ $\mathrm{T}$ cells (Figure 1, F-J). The expansion, contraction, and homeostasis of alloreactive $\mathrm{CD} 8^{+} \mathrm{T}$ cells in a BALB/c $\left(\mathrm{H}-2^{\mathrm{d}}\right)$ to $\mathrm{C} 57 \mathrm{BL} / 6$ $\left(\mathrm{H}-2^{\mathrm{b}}\right)$ skin transplant model was similar to LCMV acute infection as previously described (9). CD122 expression on alloreactive $\mathrm{CD}^{+} \mathrm{T}$ cells was comparable to the LCMV-specific response and was similarly highest on central memory $\mathrm{CD} 8^{+} \mathrm{T}$ cells $\left(\mathrm{T}_{\mathrm{CM}}\right)$ compared with effector memory CD8 ${ }^{+} \mathrm{T}$ cells $\left(\mathrm{T}_{\mathrm{EM}}\right)\left(\mathrm{CD} 122 \mathrm{MFI}_{\mathrm{CM}}=\right.$ 1,545 vs. $\mathrm{T}_{\mathrm{EM}}=564, P=0.0016$, Figure $\left.1 \mathrm{~J}\right)$. CD122 expression was increased at distant memory time points where $\mathrm{CD} 122^{+} \mathrm{T}$ cells are increasingly of a $\mathrm{T}_{\mathrm{CM}}$ phenotype (Figure $1 \mathrm{H}$ ). These findings suggest an important role for CD122 signaling in alloimmunity and potentially a distinctive role in alloreactive $\mathrm{CD} 8^{+} \mathrm{T}$ cell memory.

CD122 signaling underlies costimulation-independent rejection. Immunosuppressive strategies employing $\mathrm{CoB}$ have already shown promise in kidney transplant recipients, but wider adoption has been limited in part due to significantly elevated rates of $\mathrm{T}$ cell-mediated acute rejection $(5-7,33)$. We sought to investigate the role of CD122 signaling in costimulation-independent rejection. $\mathrm{C} 57 \mathrm{BL} / 6\left(\mathrm{H}-2^{\mathrm{b}}\right)$ recipients of $\mathrm{BALB} / \mathrm{c}\left(\mathrm{H}-2^{\mathrm{d}}\right)$ skin allografts undergo vigorous $\mathrm{CoB}$-resistant rejection during primary challenges (median survival time $[\mathrm{MST}]=21$ days with $\mathrm{CoB}$ vs. $\mathrm{MST}=$ 10 days without treatment, Figure 2A). Mice receiving anti-CD122 alone rejected with similar kinetics to untreated mice (MST = 10 days, Figure 2A). CoB extended graft survival modestly compared with control animals (21 days vs. 10 days, Figure $2 \mathrm{~A}$ ), but 

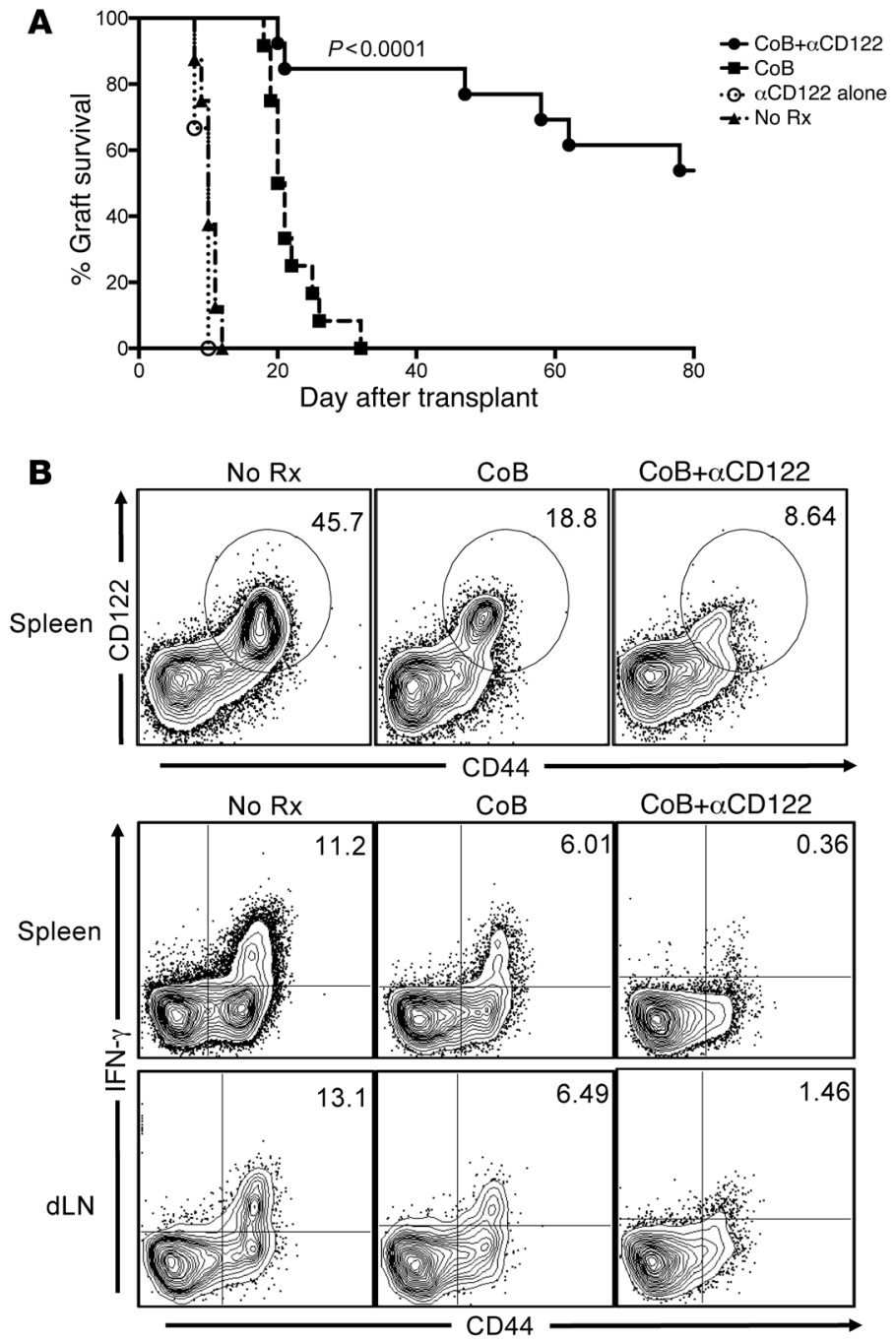

Frequency of Absolute no. of splenic $\mathrm{CD} 8^{+} \mathrm{T}$ cells splenic $\mathrm{CD} 8^{+} \mathrm{T}$ cells
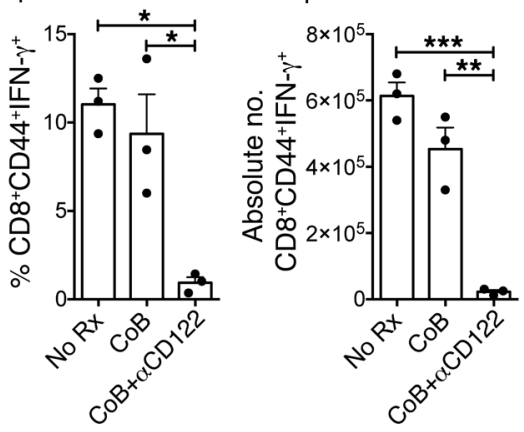

Frequency of dLN CD8 ${ }^{+} T$ cells

Absolute no. of

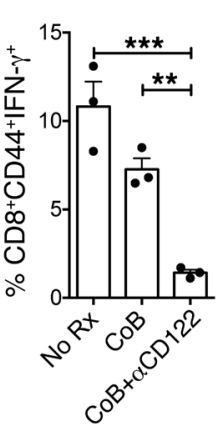
dLN CD8 ${ }^{+} \mathrm{T}$ cells

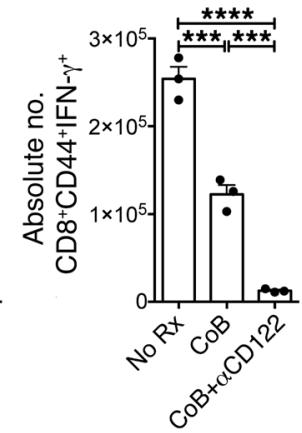

C
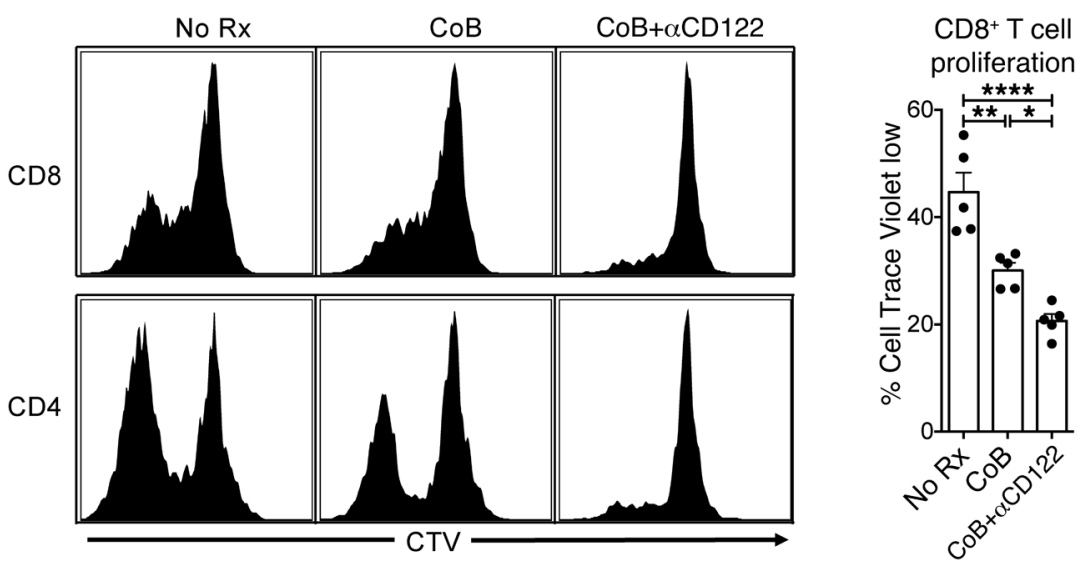

$\mathrm{CD}^{+} \mathrm{T}$ cell proliferation

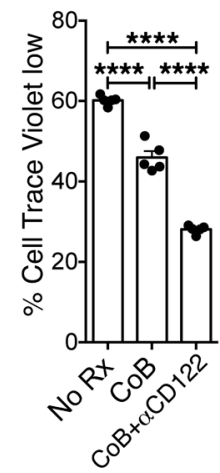


Figure 2. CD122 signaling underlies costimulation-independent rejection. (A) Median survival time (MST) of BALB/c skin allografts on C57BL/6 recipients without treatment was 10 days (black triangles, No Rx). Anti-CD122 alone failed to improve graft survival (open circles, MST $=10$ days). Mice treated with $\mathrm{CoB}$ (CTLA4-Ig+ $\alpha \mathrm{CD} 4 \mathrm{OL}$ ) succumb to costimulation-independent rejection (black squares, MST $=21$ days). Combination $\mathrm{CoB}+\alpha \mathrm{CD} 122$ prolongs survival to greater than 80 days, preventing costimulationindependent rejection in the majority of recipients $(n=6-13$ per group, representative of 3 independent experiments, $P<0.0001$, Mantel-Cox log-rank test). (B) Mice were sacrificed at day 10 after transplant. Representative FACS plots of splenocytes from untreated (No Rx), CoB, and $\mathrm{CoB}+\alpha \mathrm{CD} 122$-treated animals. $\mathrm{CoB}+\alpha \mathrm{CD} 122$ resulted in reduced frequency of alloreactive $\mathrm{CD} 44^{+} \mathrm{CD} 122^{+} \mathrm{CD} 8^{+} \mathrm{T}$ cells. Correspondingly, there is marked decrease in frequency of CD44+IFN- $\gamma^{+} \mathrm{CD}^{+}$T cells in both the spleen $(P=$ $0.0048)$ and $\operatorname{dLN}(P=0.0009)$, as well as a reduction in absolute numbers of alloreactive $\mathrm{CD} 44^{+} \mathrm{IFN}-\gamma^{+} \mathrm{CD} 8^{+} T$ cells in the spleen $(P=0.0002)$ and $\mathrm{dLN}$ $(P<0.0001)$. (C) In a model of acute graft-versus-host disease, C57BL/6 splenocytes were labeled with CTV and transferred into sublethally irradiated $B A L B / c$ recipients, which were either untreated (No Rx), treated with $\mathrm{CoB}$, or treated with $\mathrm{CoB}+\alpha \mathrm{CD} 122$. After 72 hours, splenocytes were harvested and assessed for CTV-labeled cell division as depicted in representative histograms. Both $\mathrm{CD}^{+}(P<0.0001)$ and $\mathrm{CD}^{+}(P<0.0001)$ alloproliferation was significantly constrained with combination $\mathrm{CoB}+\alpha \mathrm{CD} 122$ treatment. $P$ values were generated by 1-way ANOVA followed by Tukey's multiple comparisons test; bars represent the mean \pm SEM of 3-5 mice per group (B-C). Results are representative of 3 independent experiments. ${ }^{*} P<0.05 ;{ }^{* *} P<0.01 ;{ }^{* * *} P<0.001 ;{ }^{* * *} P<0.0001$.

combined CD122 and CoB prevented costimulation-independent rejection and prolonged allograft survival significantly (MST $>80$ days, $P<0.0001$, Figure 2A). These data suggest that signaling through CD122 as part of either the IL-2 and/or the IL-15 receptor is critical for costimulation-independent rejection. We investigated the mechanisms underlying the survival benefit observed in animals treated with $\mathrm{CoB}+$ anti-CD122. $\mathrm{CoB}$ alone fails to completely suppress alloreactive $\mathrm{CD} 8^{+} \mathrm{T}$ cells, but the addition of CD122 blockade efficiently mitigates the generation of an alloimmune response (Figure 2, B and C). Combination therapy reduced both the expansion and effector function of alloreactive $\mathrm{T}$ cells by nearly 10 -fold compared with $\mathrm{CoB}$, and 20 -fold compared with unmodified rejection (absolute number of dLN CD8 ${ }^{+}$ CD $44^{+}$IFN- $\gamma^{+}=2.54 \times 10^{5}$ in no treatment [No Rx] vs. $1.23 \times 10^{5}$ in $\mathrm{CoB}$ vs. $1.27 \times 10^{4}$ in $\mathrm{CoB}+$ anti-CD122, $P<0.0001$, Figure $\left.2 \mathrm{~B}\right)$. In a model of graft-versus-host disease we found similar effects of combined $\mathrm{CoB}$ and anti-CD122 on alloreactive $\mathrm{T}$ cell proliferation and effector function (Figure 2C). These data suggest that in the absence of traditional costimulatory signals such as CD28 and CD154, signaling through CD122 supports the expansion, activation, and effector function of naive alloreactive $T$ cells through the effects of IL-2 and/or IL-15.

CD122 signaling supports costimulation-independent memory responses. Immune memory can significantly contribute to transplant rejection $(34,35)$. Memory $\mathrm{T}$ cells can readily function without the requirement of traditional costimulatory signals, resulting in allograft rejection despite $\operatorname{CoB}(9,36-38)$. Previous studies outlined an important role for IL-15 in memory T cell homeostasis, but the role of IL-2 and IL-15 in the generation of effective memory T cell responses remains unclear, with some groups demonstrating a critical role for IL-2 in the generation of effective recall responses, whereas others have shown an important role for IL-15 signaling in recall $(22,26,32,39-43)$. Further confounding efforts to understand the respective contribution of these cytokines in generating memory responses is the role of costimulatory signals, particularly the CD40-CD154 pathways, which can support recall responses $(44,45)$. Thus, we investigated the role of IL-2R and IL-15R signaling in $\mathrm{CD} 8^{+} \mathrm{T}$ cell recall in the setting of CoB. OVA-specific $\mathrm{CD}^{+} \mathrm{T}$ cells (OT-I) were transferred into naive $\mathrm{C} 57 \mathrm{BL} / 6$ recipients and immunized with Listeria monocytogenes engineered to express chicken ovalbumin (Lm-OVA). After 30 days, mice were rechallenged with OVA-expressing skin grafts (Figure $3 \mathrm{~A}$ ). In the context of memory $\mathrm{CD} 8^{+} \mathrm{T}$ cell-mediated transplant rejection, anti-CD122 synergized with $\mathrm{CoB}$ to prolong graft survival indefinitely (MST $>100$ days, $P<0.0001$, Figure $3 \mathrm{~B}$ ). CoB alone fails to significantly prolong graft survival (MST $=16$ days). Animals treated with anti-CD122 alone rejected with similar kinetics to animals who received no therapy (MST $=11$ days). We investigated the phenotypic and functional effects underlying prolonged graft survival in a model of memory $\mathrm{CD}^{+} \mathrm{T}$ cell-mediated acute graft rejection. $\mathrm{CoB}$ alone did not significantly reduce the frequency of graftreactive $\mathrm{CD} 8^{+}$memory $\mathrm{T}$ cells compared with untreated mice (Figure 3, C and D). The addition of anti-CD122 to CoB dramatically constrained the expansion and effector function of graft-reactive cells (Figure 3, C and D). Further, we observed a change in phenotype, where the combination of anti-CD122 and $\mathrm{CoB}$ induced a PD- $1^{\text {hi }} C T L A 4^{\text {hi }}$ exhausted phenotype on antigen-specific CD $8^{+}$ $\mathrm{T}$ cells (Figure 3E). CoB+anti-CD122 reduced Ki67 expression in graft-reactive memory $\mathrm{CD} 8^{+} \mathrm{T}$ cells as well, suggesting that the difference in numbers was due at least in part to decreased expansion/proliferation (Figure 3E). These data suggest that signaling through the shared IL-2/IL-15R $\beta$ chain during recall responses is critical for memory $\mathrm{CD} 8^{+} \mathrm{T}$ cell proliferation and effector function; however, the relative importance of IL-2R versus the IL-15R remained undetermined.

Antigen-specific memory $T$ cells do not require the high-affinity $I L-2 R$ to mediate CoB-resistant rejection. Currently approved immunosuppressive strategies for transplant recipients include the use of anti-CD25 therapies $(46,47)$. The role of IL-2 and IL-15 in the generation of recall responses is the subject of great interest for vaccine development, cancer immunotherapy, autoimmunity, and transplantation (31). We investigated the impact of the addition of a short course of anti-CD25 mAb as an adjuvant therapy to $\mathrm{CoB}$ in this memory $\mathrm{T}$ cell-mediated model of graft rejection. The addition of anti-CD25 failed to prolong graft survival (MST $=22$ days, Figure 4A), whereas the addition of anti-CD122 therapy, which blocks IL-15 and IL-2 signaling, prolonged graft survival indefinitely and controlled the expansion of graft-reactive memory $\mathrm{T}$ cells, relative to $\mathrm{CoB}$ or $\mathrm{CoB}+$ antiCD25 (Figure 4, B and C). Mice who received OT-1 adoptive transfer and Lm.OVA immunization but no skin graft challenge were labeled "No Challenge" and utilized as controls. Combined $\mathrm{CoB}+$ anti-CD25 failed to control the frequency of cells entering the cell cycle compared with the significant reduction in animals treated with $\mathrm{CoB}+$ anti-CD122, as measured by the frequency of cells expressing Ki67 (mean frequency \pm SEM of Ki67 ${ }^{+}$of Thy1.1 $1^{+}$ $=22.58 \pm 2.58$ in No Rx vs. $14.2 \pm 1.71$ in $\mathrm{CoB}$ vs. $7.66 \pm 0.55$ in $\mathrm{CoB}+$ anti-CD122 vs. $26.28 \pm 2.52$ in $\mathrm{CoB}+$ anti-CD25 vs. 12.81 \pm 1.59 in No Challenge, $P<0.0001$, Figure 4D). This increased 
A
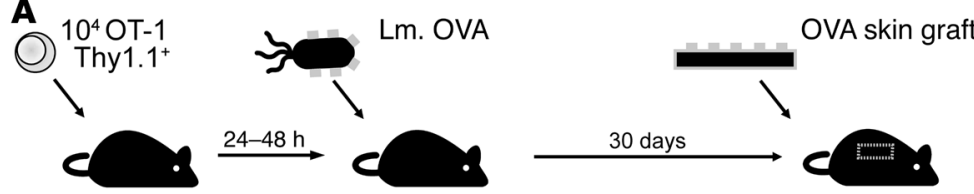

C

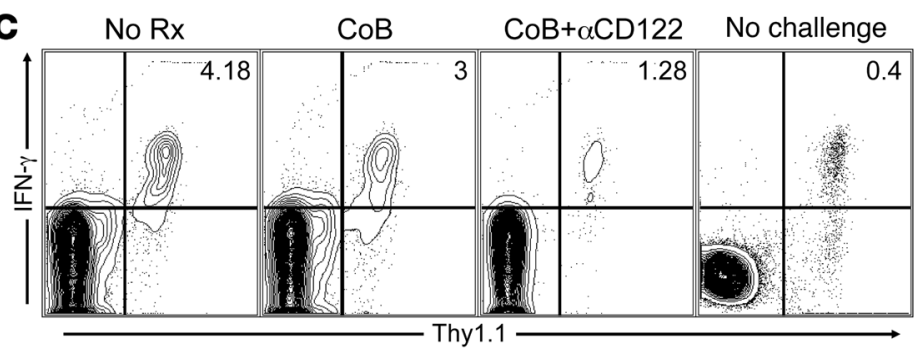

D

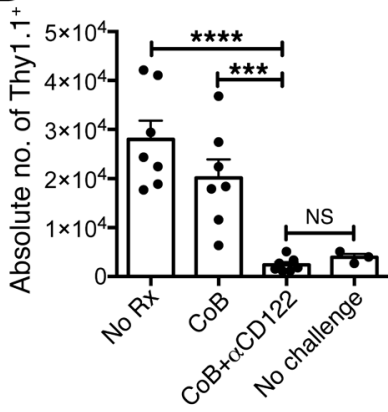

E

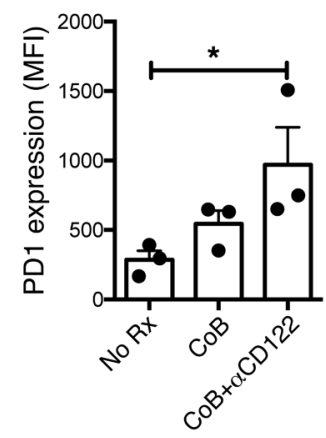

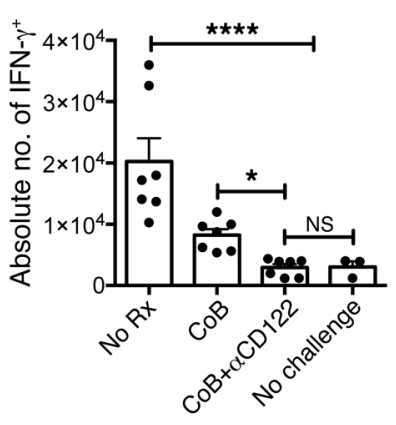

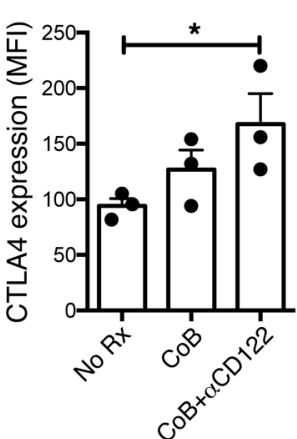

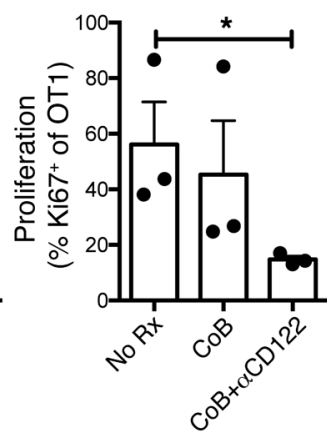
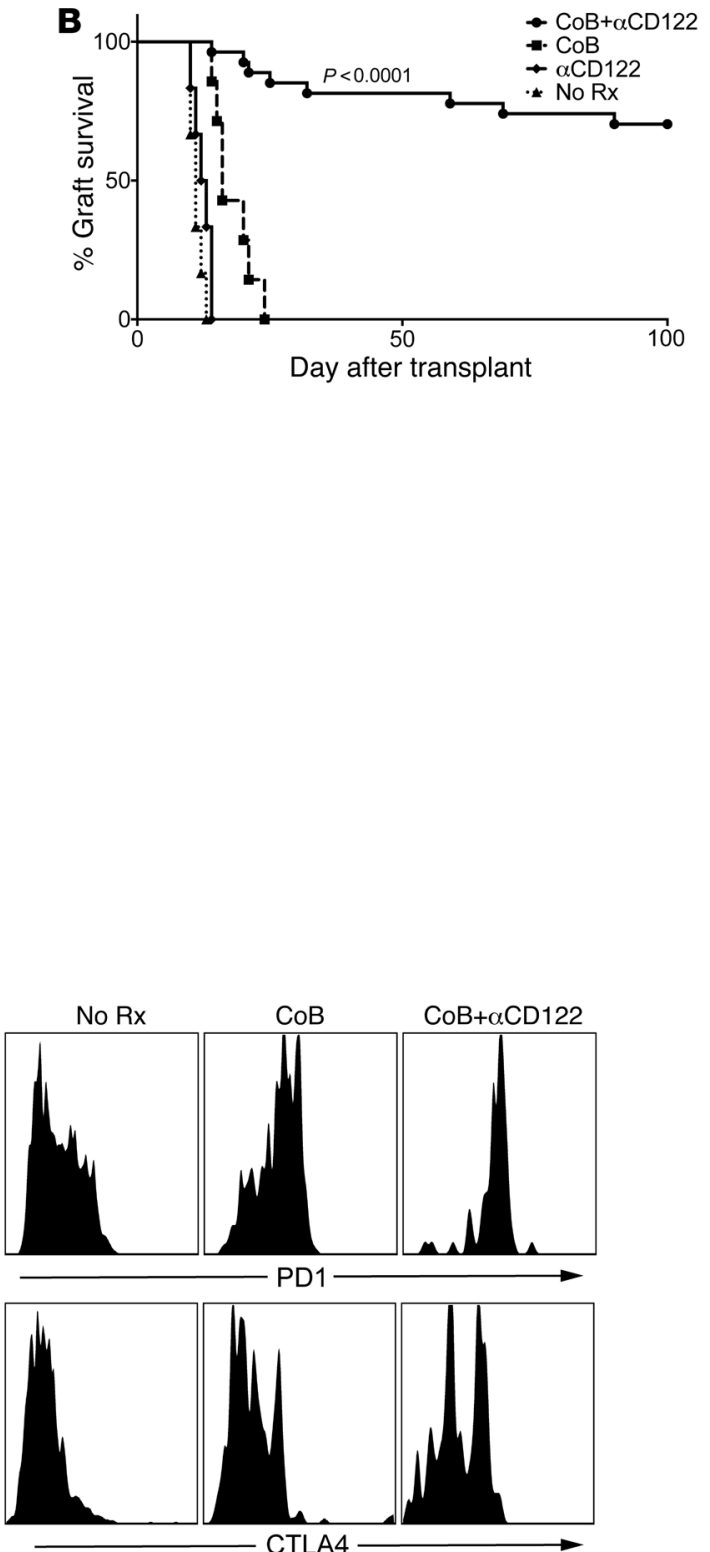

Figure 3. CD122 signaling supports costimulation-independent recall responses. (A) In a model of memory CD8 ${ }^{+} \mathrm{T}$ cell-mediated graft rejection, OVAspecific CD8 ${ }^{+}$T cells (Thy1.1+OT-1) were transferred into naive C57BL/6 mice. Mice were immunized 24-48 hours later with Listeria monocytogenes expressing ovalbumin (Lm.OVA). After 30 days, mice were challenged with an OVA-expressing skin graft. (B) Untreated mice experienced rapid acute rejection (black triangles, No Rx, MST = 11). Mice treated with $\alpha$ CD122 rejected their skin grafts with similar kinetics to untreated mice (black diamonds, $\alpha$ CD122, MST $=13$ ). $\mathrm{CoB}$ treated mice experienced memory CD8 ${ }^{+} \mathrm{T}$ cell mediated costimulation independent rejection shortly after (black squares, CoB, MST=16). Addition of $\alpha$ CD122 synergized with CoB to prolong graft survival indefinitely (black circles, CoB $+\alpha C D 122$, MST $>100$ days, $n=6-13 / g r o u p, P<0.0001$ Mantel-Cox log-rank test). (C) We investigated the impact of $\mathrm{CoB}+\alpha \mathrm{CD} 122$ by examining the frequency and function of graft specific CD8 ${ }^{+} \mathrm{T}$ cells in the draining lymph nodes 5 days after transplantation. Addition of $\alpha$ CD122 constrains the expansion of graft specific CD8 ${ }^{+} T$ cells as demonstrated in representative FACS plots. (D) Both absolute number of graft specific (Thy1.1+) cells $(P<0.0001)$ and IFN- $\gamma^{+}$cells $(P<0.0001)$ were diminished with the addition of $\alpha \mathrm{CD} 122$. (E) $\mathrm{CoB}+\alpha \mathrm{CD} 122$ therapy resulted in increased coinhibitory receptor expression on remaining graft specific CD8 $8^{+} \mathrm{T}$ cells. Thy1.1 ${ }^{+}$cells demonstrated increased PD-1 $(P=0.0303)$ and CTLA4 $(P=0.0065)$ expression. Additionally, decreased Ki67 expression $(P=0.0250)$ indicated reduced cell-cycle entry. (C-E) $P$ values were generated by 1-way ANOVA followed by Bonferroni's multiple comparisons test. Bars represent the mean \pm SEM of 3-7 mice per group. Results are representative of 5 independent experiments. ${ }^{*} P<0.05 ;{ }^{* * *} P<0.001 ;{ }^{* * *} P<0.0001$.

cell cycle entry may be due to inhibition or reduction of Tregs in CoB+anti-CD25-treated mice.

Previous studies underscored the importance of the highaffinity IL-2 receptor in costimulation-independent rejection during a primary allo-immune response (48). Our studies confirmed these results, demonstrating that both anti-CD25 and
anti-CD122 synergize with $\mathrm{CoB}$ to prolong graft survival during a primary response (Figure $4 \mathrm{E}$ ). These data suggest that the IL-15R receptor is necessary for costimulation-independent memory $\mathrm{T}$ cell responses, whereas the high-affinity IL-2R receptor is dispensable. In the setting of a primary allo-immune challenge, costimulation-independent cells rely on the high-affinity IL-2 receptor. Tar- 
A

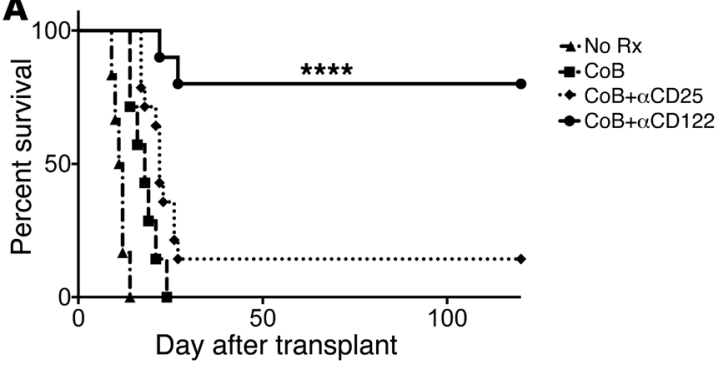

B

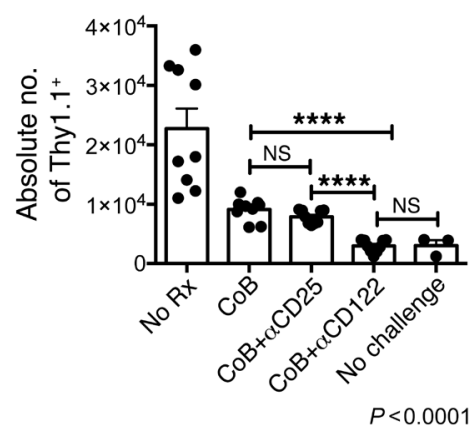

C

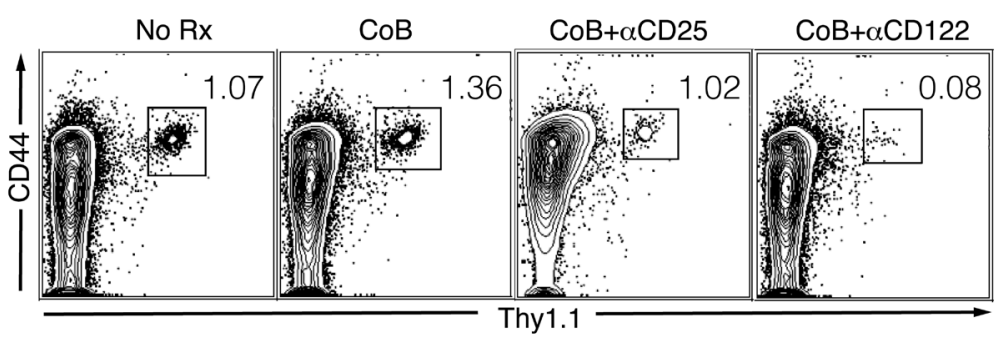

D
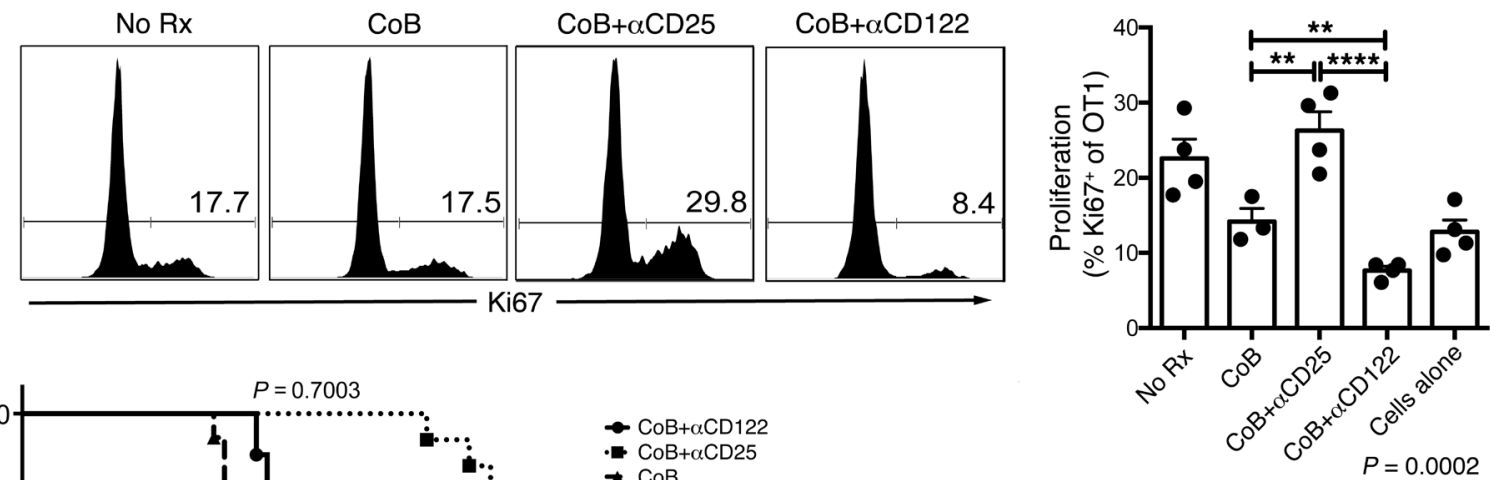

E

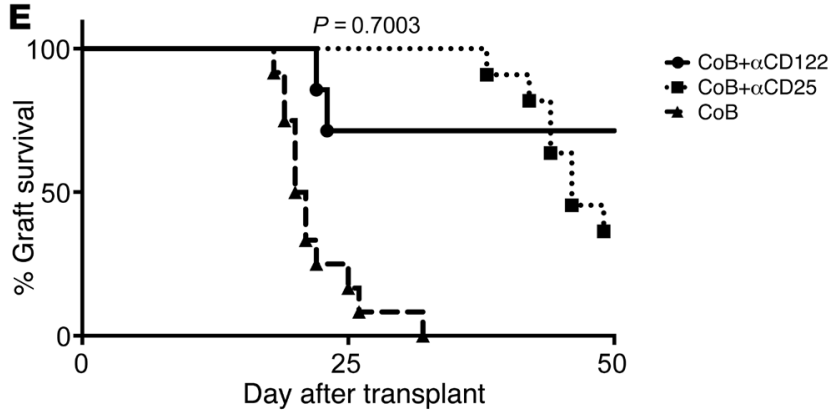

$P=0.0002$

Figure 4. Antigen-specific memory T cells do not require high-affinity IL-2R to mediate CoB resistant rejection. (A) Utilizing the same model of memory CD8 ${ }^{+} T$ cell mediated graft rejection as modeled in Figure 3, we evaluated the relative importance of the high-affinity IL-2 receptor by blocking CD25, compared with blocking CD122, which interrupts both the IL-2R and IL-15R. Untreated mice rejected rapidly (black triangle, MST = 11 days). CoB alone led to costimulation-independent rejection (black squares, MST $=16$ days). Combined CoB $+\alpha C D 25$ (black diamonds, MST = 23 days) failed to prevent memory CD8 T cell-mediated CoB-resistant rejection, whereas combined $\mathrm{CoB}+\alpha \mathrm{CD} 122$ resulted in indefinite graft survival in the majority of transplant recipients (black circles, MST $>100$ days, $P<0.0001, n=6-13$ per group, Mantel-Cox log-rank test). (B) CoB+ $\alpha$ CD122 synergistically controlled the expansion of antigen-specific $C D 8^{+} T$ cells during recall responses more effectively than $\mathrm{CoB}$ or $\mathrm{CoB}+\alpha \mathrm{CD} 25(P<0.0001)$. (C) Representative FACS plot demonstrate reduced frequency of antigen-specific cells in $\mathrm{CoB}+\alpha \mathrm{CD} 122$-treated animals compared with $\mathrm{CoB}$ or $\mathrm{CoB}+\alpha \mathrm{CD} 25$. (D) CoB $+\alpha C D 122$ therapy resulted in a significant reduction of antigen-specific cells entering cell cycle, demonstrated by reduced Ki67 expression in representative histograms and the corresponding graph comparing $\mathrm{CoB}+\alpha \mathrm{CD} 122$ versus $\mathrm{CoB}$ or $\mathrm{CoB}+\alpha \mathrm{CD} 25(P=0.0002)$. (E) In the $\mathrm{BALB} / \mathrm{C}$ to $[57 \mathrm{BL} / 6$ skin transplant model, a primary alloimmune challenge, the addition of $\alpha \mathrm{CD} 25$ therapy (black squares), which interrupts the high-affinity IL-2R, demonstrated similar efficacy in prolonging allograft survival as the addition of $\alpha$ CD122 (black circles), which blocks both the IL-2R and IL-15R complexes. $P$ values were generated by 1-way ANOVA followed by Bonferroni's multiple comparisons test. Bars represent the mean \pm SEM of 3-9 mice per group. Results are representative of 5 independent experiments. ${ }^{* *} P<0.01,{ }^{* * *} P<0.0001$.

geting CD122 interrupts both the IL-2 and IL-15 receptors, without the potential unwanted effects of anti-CD25 therapies on Tregs.

CD122 phenotype and function in rhesus macaques. In an effort to evaluate whether these findings were potentially translatable to patients we sought to characterize the phenotype and function of CD122 on $\mathrm{CD}^{+} \mathrm{T}$ cells in a preclinical model using rhesus macaques. We first characterized CD122 expression on CD8 T cells using an appropriate isotype control (Figure 5, A-E). CD122 
A

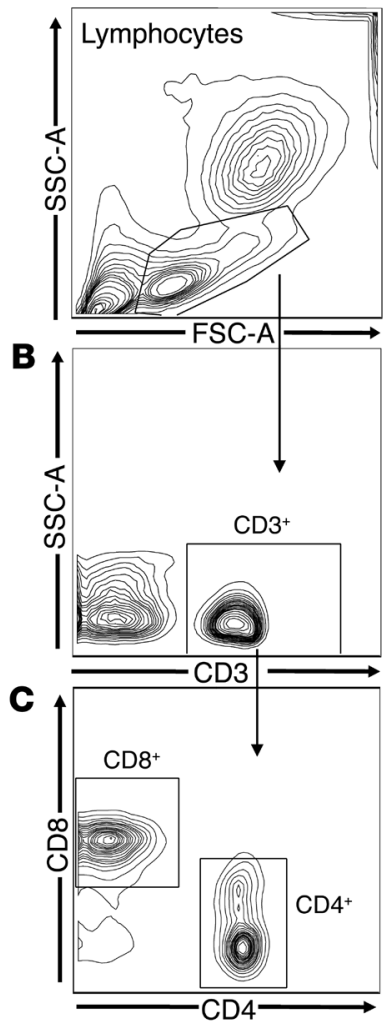

$\mathbf{K}$
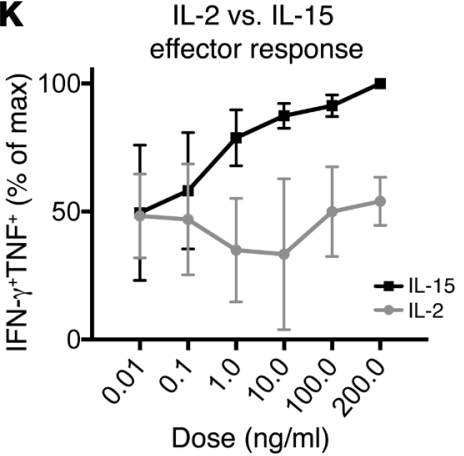

Dose (ng/ml)
D
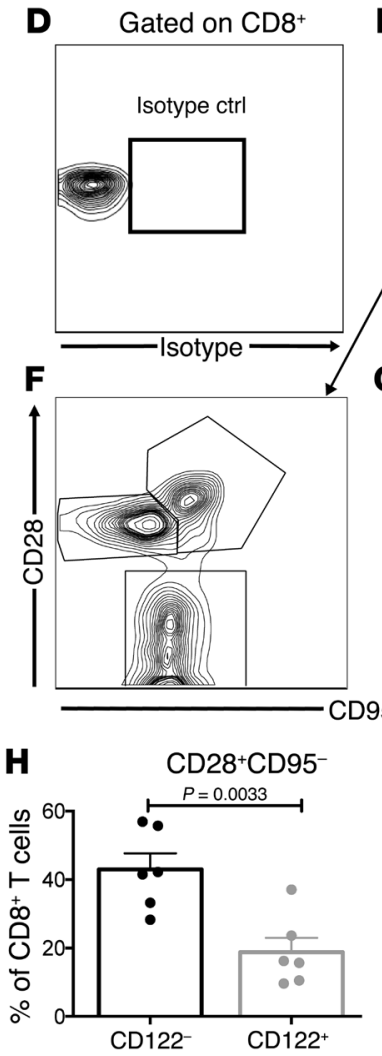

E Gated on CD8 ${ }^{+}$

CD122- CD122+

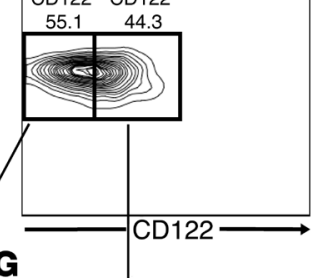

(2)
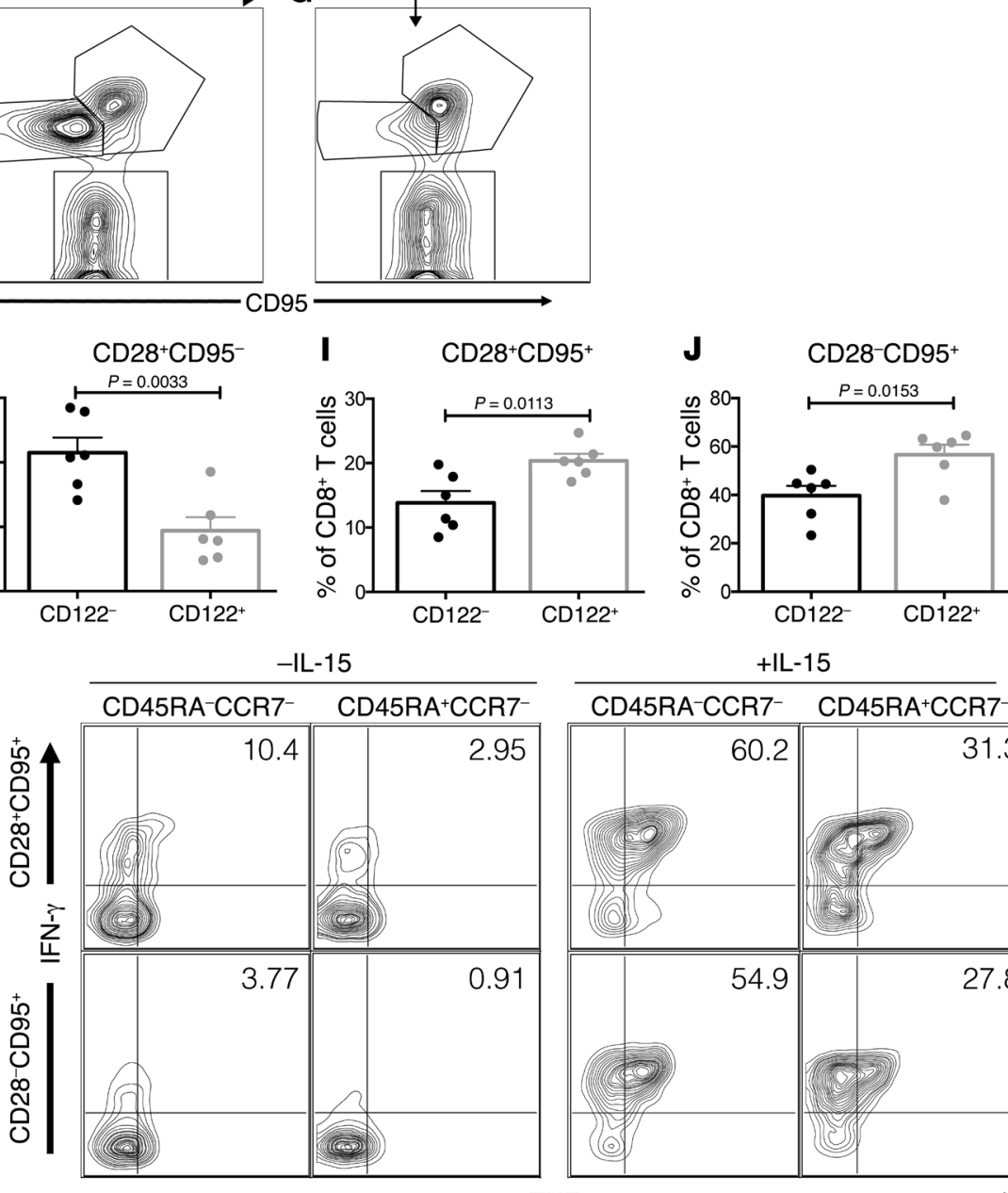

$\frac{+\mathrm{IL}-15}{\text { CD45RA-CCR7 }^{-} \text {CD45RA }{ }^{+C C R 7}}$

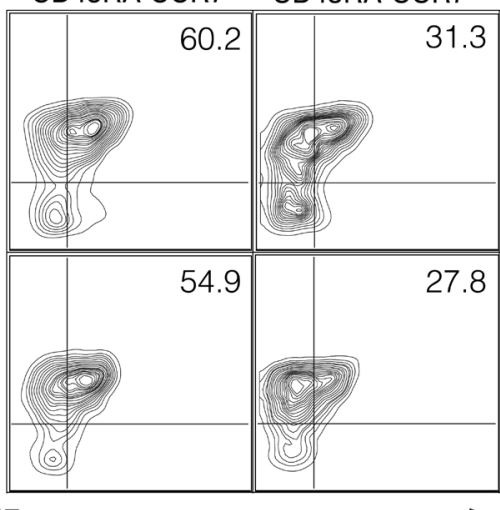

TNF

$\mathbf{L}$

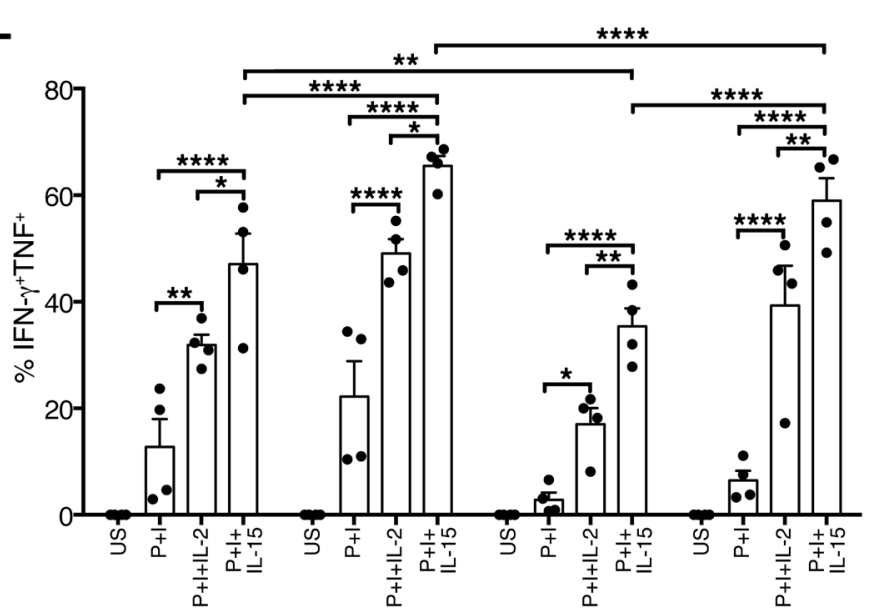

$\overline{\text { CD45RA+CCR7- }^{-}} \overline{\text { CD45RA-CCR7- }} \overline{\text { CD45RA+CCR7 }}-\overline{\text { CD45RA-CCR7 }^{-}}$

$$
\mathrm{CD}^{+} \mathrm{C}^{+} \mathrm{CD} 95^{+}
$$

$\mathrm{CD}^{-}{ }^{-} \mathrm{CD} 95^{+}$ 
Figure 5. CD122 phenotype and function on rhesus macaque CD8 $\mathrm{T}$ cells. (A) Rhesus PBMCs were analyzed by FACS. Gates based on lymphocytes were defined by forward and side-scatter, (B) further gated on $\mathrm{CD}^{+} \mathrm{T}$ cells and then (C) CD8 ${ }^{+} \mathrm{T}$ cells and $\mathrm{CD} 4^{+} \mathrm{T}$ cells. (D) Gating on $\mathrm{CD} 8^{+} \mathrm{T}$ cells, an isotype control was utilized to define (E) $\mathrm{CD} 122^{-}$versus $\mathrm{CD} 122^{+} \mathrm{CD}^{+} \mathrm{T}$ cells. (F) CD122- cells demonstrated higher frequencies of CD28 ${ }^{+} \mathrm{CD} 95^{-}$naive CD8 ${ }^{+} T$ cells in contrast to (G) CD122+ cells which were predominantly $T_{E M}$

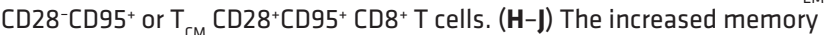
phenotype of $\mathrm{CD} 122^{+}$(gray bars) $\mathrm{CD} 8^{+} \mathrm{T}$ cells versus the more naive phenotype of CD122- (black bars) CD8 ${ }^{+} T$ cells is depicted graphically. (K) The addition of IL-15 in vitro increased frequencies of $\mathrm{CD} 8^{+} T$ cells recruited into the effector response as measured by dual IFN- $\gamma$ and TNF production. IL-15 augments effector function across the spectrum of memory differentiation, as defined by CD28, CD95, CD45RA, and CCR7 expression. (L) IL-15 was superior to IL-2 in recruiting CD8 ${ }^{+} \mathrm{T}$ cells into an effector response. IL-15 augments cytokine production by CD28+CD95+ cells compared with CD28-CD95 ${ }^{+}$cells $(P<0.0001)$. (H-J) $P$ values were generated by Student's $t$ test, 2-tailed. (L) $P$ values were generated by 1-way ANOVA followed by Tukey's multiple comparisons test; bars represent the mean \pm SEM of 3-6 rhesus macaques. Results are representative of 3 independent experiments. ${ }^{*} P<0.05 ;{ }^{* *} P<0.01 ;{ }^{* * *} P<0.0001$.

is highly expressed on $\mathrm{T}_{\mathrm{CM}}\left(\mathrm{CD} 28^{+} \mathrm{CD}^{+}\right)$and $\mathrm{T}_{\mathrm{EM}}\left(\mathrm{CD} 28^{-} \mathrm{CD} 95^{+}\right)$ but not naive $\left(\mathrm{CD} 28^{+} \mathrm{CD}^{-} 5^{-}\right) \mathrm{CD}^{+} \mathrm{T}$ cells (Figure $\left.5, \mathrm{~F}-\mathrm{J}\right)$. Next, we assessed the effector function of $\mathrm{CD}^{+}$memory $\mathrm{T}$ cell subsets and the relative effects of exogenous IL-2 and IL-15. The addition of IL-15 for 5 hours dramatically increased effector cytokine production by CD $8^{+} \mathrm{T}$ cells, more so than IL-2 (Figure 5, K and L). Analysis of intergroup differences revealed that in all memory subsets, IL-15 was more potent at recruiting cells into an effector response when compared with IL-2 (Figure 5L). Increasing, albeit supra-therapeutic, concentrations of IL-2 may elicit similar responses (Figure $5 \mathrm{~K}$ ). We have previously reported that $\mathrm{CD} 28^{+}$memory $\mathrm{T}$ cells in rhesus monkeys and humans predict CoB-resistant rejection $(12,13)$. We found $\mathrm{CD} 28^{+}$memory T cells more responsive to exogenous IL-15 than CD28- memory T cell subsets (Figure $5 \mathrm{~L}$ ). To better understand the mechanism(s) by which CD122 signaling contributes to alloreactivity, we utilized an ex vivo mixed lymphocyte reaction with NHP PBMCs. We found that IL-15 augmented alloreactivity, specifically by increasing proliferation and effector function, and IL-15 induced a loss of CD28 expression in $\mathrm{CD}^{+} \mathrm{T}$ cells (Figure 6, A and B). Belatacept fails to inhibit alloreactivity in vitro, but the addition of a humanized CD122-specific monoclonal antibody (HuABC2) synergistically inhibits proliferation, effector function, and $\mathrm{CD} 28$ downregulation in $\mathrm{CD}^{+} \mathrm{T}$ cells without evidence of increased cell death (Figure 6, A and B). These data suggest CD122 signaling, particularly via IL-15, in primate CD8 ${ }^{+} \mathrm{T}$ cells is sufficient to support costimulation-independent responses, and in fact CD122 signaling drives the loss of the costimulatory molecule CD28 while augmenting proliferation and effector function, potentiating therapeutic resistance to CD28-directed therapies, such as belatacept.

A humanized anti-CD122 mAb synergizes with belatacept to significantly prolong allograft survival in NHPs. We next tested whether treatment with a humanized anti-CD122 antibody would impact CoB-resistant rejection in a NHP kidney transplant model (Figure $6 \mathrm{C})$. This rigorous model gives rise to allograft rejection that is resistant to $\mathrm{CoB}$ with belatacept monotherapy (1). We observed no survival benefit in animals treated with anti-CD122 monotherapy
( $n=2, \mathrm{MST}=7$ days, Figure 6C). The combination of CoB using belatacept and anti-CD122 significantly prolonged kidney transplant survival in NHPs $(n=5$, MST $=138$ days, $P<0.0001$, Figure 6C). We did not observe a marked increase in viral reactivation, confirming an absence of overt over-immunosuppression (Supplemental Figure 1; supplemental material available online with this article; https://doi.org/10.1172/JCI95914DS1). These data indicate that belatacept-resistant rejection relies on CD122 signaling. We assessed the impact of combined belatacept plus antiCD122 as compared with belatacept alone and found no significant impact on T cell subsets (Figure 7A). Belatacept+anti-CD122 improved survival compared with belatacept alone; however, the kinetics of rejection on combination therapy allowed for further intragroup comparison. Two animals, $\mathrm{C} 1$ and $\mathrm{C} 2$, rejected on combination therapy (day 35 and day 67) whereas one animal rejected after cessation of anti-CD122 (C3, day 148), and 2 animals rejected after withdrawal of both anti-CD122 and belatacept (C4, day 177 and C5, day 218). Further analysis revealed no significant differences in pretransplant memory $\mathrm{T}$ cell immunophenotype; however, graft-infiltrating $\mathrm{CD}^{+} \mathrm{T}$ cells in animals that rejected after withdrawal of all therapy (C4 and C5) demonstrated a similar phenotype with increased CD28 ${ }^{+}$memory $\mathrm{T}$ cells. This is in contrast to animals that rejected on combination therapy (C1 and $\mathrm{C} 2)$, in which there were higher frequencies of CD28- infiltrate (C1 69\% and C2 55\% vs. C4 37.3\% and C5 37\%, Figure 7C). While there were no significant pretransplant differences in $\mathrm{T}$ cell immunophenotype between belatacept or belatacept+anti-CD122-treated animals, only 3 belatacept monotherapy animals had sufficient graft infiltrate to analyze with FACS and interestingly, all demonstrated a marked CD28- ${ }^{-}$allograft infiltrate (Figure 7, A-C). Flow cytometric characterization of belatacept-resistant rejectors revealed uniform upregulation of CD122, but not CD25, on all graft-infiltrating $\mathrm{T}$ cells at the time of rejection (Figure $7 \mathrm{C}$ ). Importantly, both belatacept and belatacept+anti-CD122-treated animals did not develop donor-specific antibody (DSA) while on combination therapy (Figure 7D).

Regulatory $\mathrm{T}$ cells play a key role in graft tolerance, and may be adversely impacted with current CD25-directed therapies. We assessed the longitudinal peripheral blood frequencies of Tregs $\left(\mathrm{CD} 4^{+} \mathrm{CD} 25^{+} \mathrm{FoxP}^{+}\right)$and found no significant impact on the frequency of Tregs with either belatacept monotherapy or the combination of anti-CD122 and belatacept (Figure 8A). We did, however, measure the frequency of $\mathrm{CD} 4^{+} \mathrm{CD} 25^{+} \mathrm{FoxP} 3^{+}$cells within graft infiltrate and found a trend toward an increased frequency of Tregs in the combination belatacept+anti-CD122treated animals (Figure 8B).

\section{Discussion}

The introduction of potent, nonspecific immunosuppression with calcineurin inhibitors dramatically improved short-term outcomes in solid organ transplantation. Despite excellent improvements early after transplantation, the late outcomes remain essentially unchanged and represent the greatest challenge for transplant recipients (49). Unfortunately, most transplant patients eventually lose their allograft from rejection or die as the result of increased cardiovascular complications or infections. The advent of $\mathrm{CoB}$ as a more targeted strategy for transplant immunosuppression has 
A Proliferation

Effector function

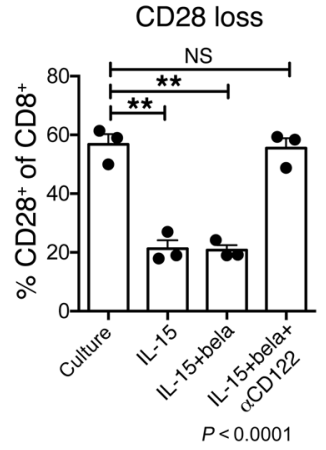

Cell death
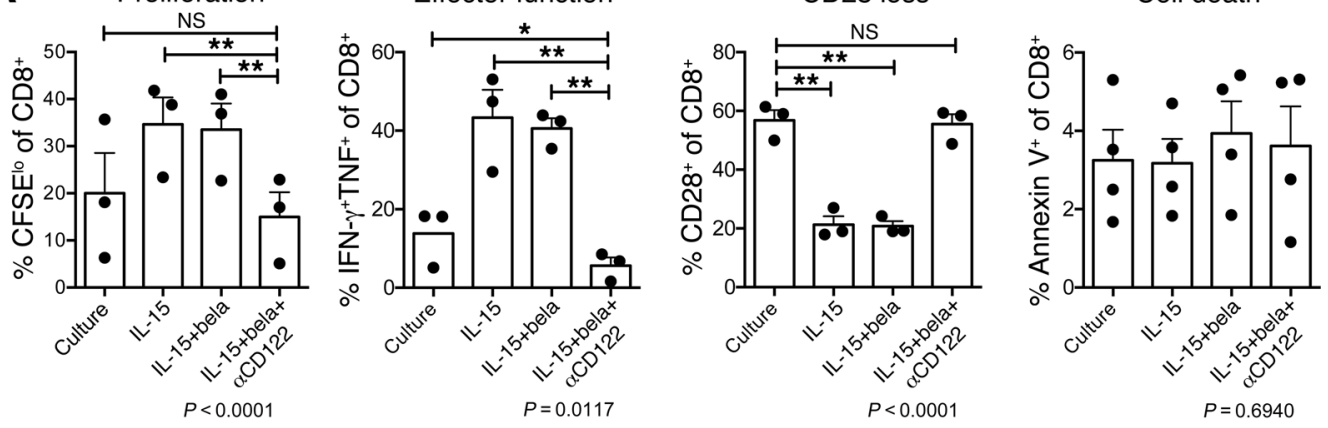

B CFSE dilution

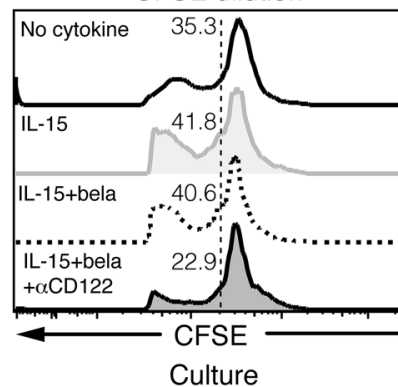

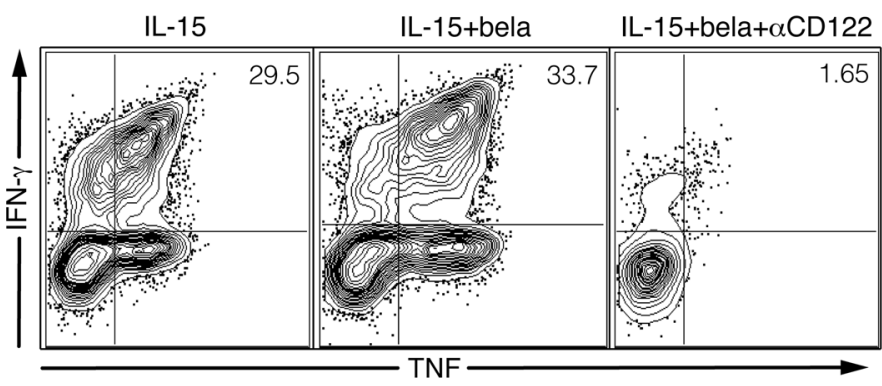

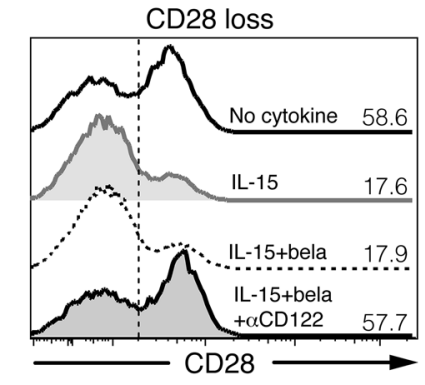

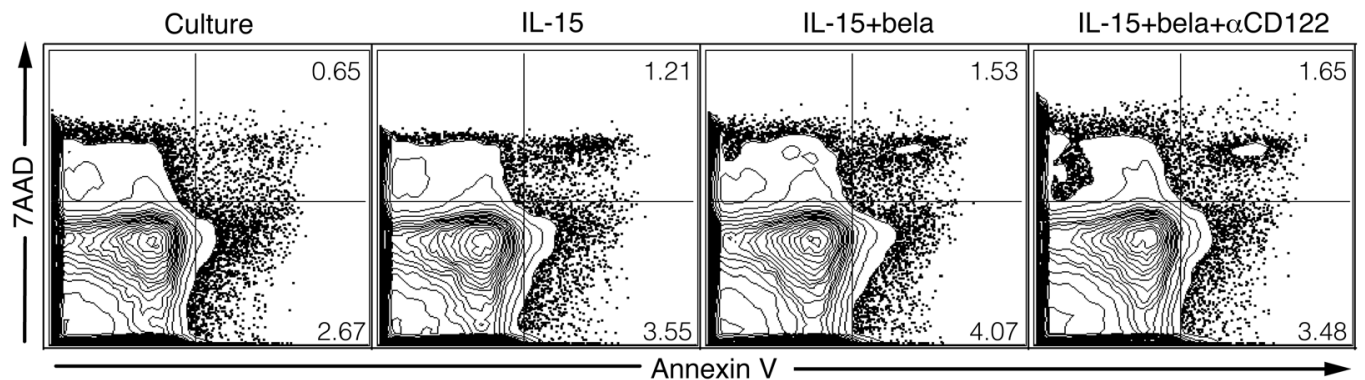

C

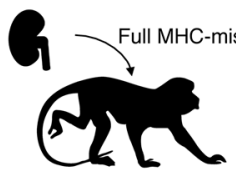

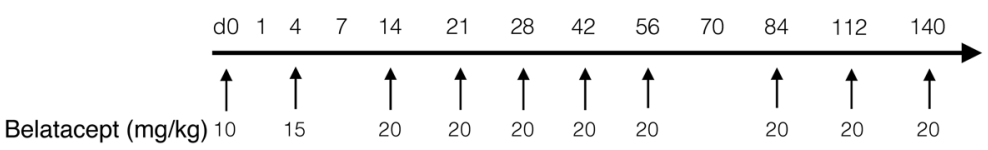

a.CD122 (5 mgkg) $\uparrow \quad \uparrow \quad \begin{array}{llllll} & \uparrow & \uparrow & \uparrow & \uparrow & \uparrow\end{array}$

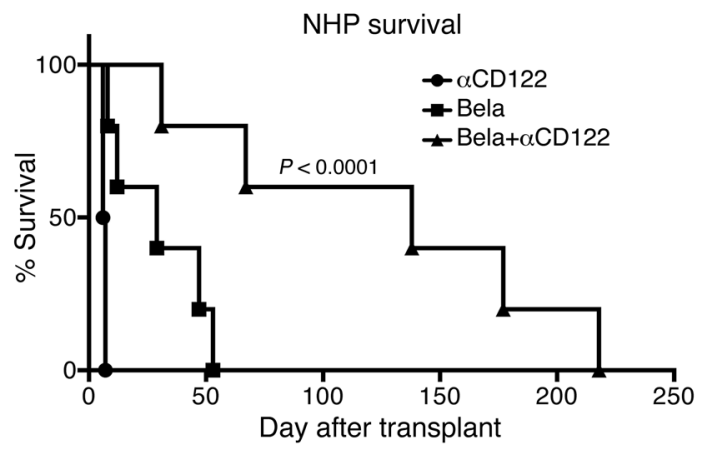

\begin{tabular}{|l|l|l|}
\hline Therapy & ID & Survival \\
\hline aCD122 & A1 & Day 6 \\
& A2 & Day 7 \\
\hline belatacept & B1 & Day 8 \\
& B2 & Day 12 \\
& B3 & Day 29 \\
& B4 & Day 47 \\
& B5 & Day 53 \\
\hline belatacept & C1 & Day 35 \\
+aCD122 & C2 & Day 67 \\
& C3 & Day 138 \\
& C4 & Day 177 \\
& C5 & Day 218 \\
\hline
\end{tabular}
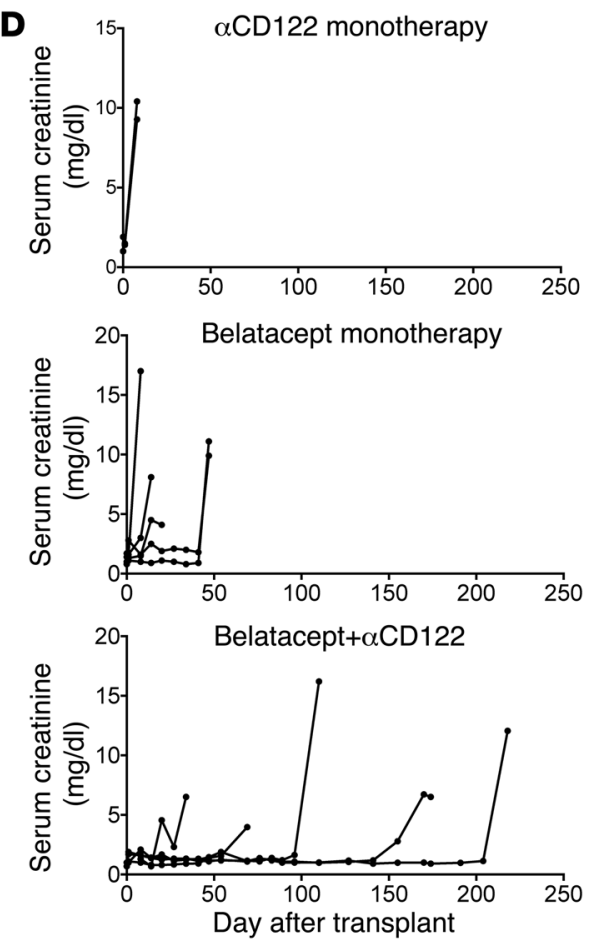
Figure 6. Humanized $\alpha$ CD122 synergizes with belatacept to inhibit alloreactivity and prolong NHP transplant survival. (A) MLR of NHP PBMCs between fully MHC-mismatched pairs. CFSE-labeled responder lymphocytes were incubated for 96 hours with irradiated stimulators (culture), with IL-15, IL-15+bela (belatacept), or IL-15+bela+ $\alpha$ CD122. The addition of belatacept alone did not suppress proliferation, effector function, or loss of CD28 expression. The combination of bela $+\alpha C D 122$ reduced proliferation $(P<0.0001)$, diminished effector function $(P=0.0117)$, and restored CD28 expression on CD8 $+T$ cells to similar levels as culture conditions without IL-15 $(P=0.8011)$. (B) Representative FACS plots of CD8 ${ }^{+} T$ cell expansion by CFSE dilution, effector function as measured by dual IFN- $\gamma$ and TNF production, and apoptosis and cell death as measured by 7-AAD and Annexin V staining (corresponds to graphs in A). (C) NHPs underwent bilateral nephrectomy and life-sustaining renal transplantation from a fully MHC-mismatched NHP donor. Animals were treated with humanized $\alpha$ CD122 alone ( $5 \mathrm{mg} / \mathrm{kg}$, black circles, $n=2$, MST $=7$ days), belatacept alone (black squares, $n=5$, MST $=29$ days), or bela $+\alpha$ CD122 (black triangles, $n$ $=5$, MST $=138$ days, $P<0.0001$, Mantel-Cox log-rank test). Combination bela $+\alpha$ CD122 synergized to prolong NHP survival compared with belatacept monotherapy, or $\alpha \mathrm{CD} 122$ monotherapy. (D) Corresponding serum creatinine curves of NHPs and demonstrated rejection were preceded by declining graft function. (A-B) $P$ values were generated by repeat measures 1-way ANOVA and Tukey's multiple comparisons test; bars represent the mean \pm SEM of 3 NHPs per group. In vitro results are representative of 3 independent experiments. ${ }^{*} P<0.05$; ${ }^{*} P<0.01$.

demonstrated the first evidence of improved long-term outcomes and graft function in the setting of clinical trials and in posttrial use $(5,7)$. However, a significant number of patients treated with belatacept experienced elevated rates and grades of acute rejection within the first 6 months of transplantation $(6,7)$. Studies that investigate $\mathrm{T}$ cell reactivity in the setting of $\mathrm{CoB}$ improve our understanding of the dynamic signaling requirements of $\mathrm{T}$ cells while addressing a pressing clinical need for safer, more specific forms of immunosuppression. Signal 2 (costimulation) and signal 3 (provided by cytokines) are synergistic and in some respects redundant; in the absence of signal 2, signal 3 cytokines can support robust responses. Here we focused our investigation on the ability of signal 3 cytokines IL-2 and IL-15 to support costimulation-independent rejection. We evaluated a strategy to block both IL-2 and IL-15 signaling with a single, CD122-directed reagent in mice, and then translated our findings into a preclinical model utilizing NHPs in order to optimize CoB strategies in the setting of transplantation. The addition of anti-CD122 offered several key advantages to current transplant immunosuppression strategies: (a) abrogation of the primary immune response, (b) superior attenuation of memory $\mathrm{CD}^{+} \mathrm{T}$ cell recall compared with strategies targeting the high-affinity IL-2R, and (c) sparing of Tregs, which are targeted by current CD25-directed therapies in transplant, with a possible increase in the frequency of intragraft Tregs in NHPs.

IL-2 and IL-15 are structurally and genetically distinct cytokines, sharing little sequence similarity. Though these cytokines share 2 signaling subunits, CD122, the shared IL-2 and IL-15 receptor $\beta$-chain, and CD132 the common $\gamma$-chain $\left(\gamma_{c}\right)$, they have distinct contact residues with CD122 and CD132 (50). Their nonredundant roles are highlighted by the divergent phenotypes of IL-2/IL-2 $\mathrm{R}^{-/-}$mice, which suffer from autoimmunity due to $\mathrm{CD} 4{ }^{+} \mathrm{CD} 25^{+}$Treg deficiency, and IL-15/IL-15R $\alpha$ knockout mice, which have decreased $\mathrm{CD}^{+} \mathrm{T}$ cells, intraepithelial lymphocytes, NK cells, and NK T cells $(17-20,51)$. Saturating doses of IL-2 and
IL-15 give rise to nearly identical $\mathrm{CD}^{+} \mathrm{T}$ cell transcriptomes (50). Thus, the temporal and spatial differences in receptor subunit expression (CD25 vs. CD122) may underlie the unique roles of IL-2 and IL-15 in the generation and maintenance of adequate adaptive immune responses as opposed to unique intrinsic signaling properties of IL-2/IL-2R $\alpha$ and IL-15/IL-15R $\alpha(50,52)$. IL-2 is readily taken up by $\mathrm{CD} 4{ }^{+} \mathrm{CD} 25^{+}$Tregs, which rapidly express the high-affinity IL-2R as predicted by high expression of CD25. On the other hand, CD122 expression is highest on $\mathrm{CD}^{+}$memory $\mathrm{T}$ cells and NK cells, allowing for formation of the high-affinity IL-15R. IL-15R $\alpha$ is expressed in trans by antigen presenting cells, as well as by a number of peripheral tissue cell types, notably in renal epithelium (53). IL-15R $\alpha$ presents IL-15 in complex and binds with 150 times greater affinity than circulating IL-15 to cells expressing CD122 and the common $\gamma$-chain $(50,53,54)$.

The current body of knowledge emphasizes a critical role for IL-2 in the generation of effective primary immune responses, memory differentiation, and recall, whereas IL-15 is conceptualized as providing homeostatic proliferative signals for memory $\mathrm{T}$ cells, and recently, potentially providing inflammatory signals to increase memory T cell cycling $(26,41,43,55-57)$. The type of immune challenge used in these studies, the chronicity and antigen load, as well as the strength and duration of cytokine signaling, influences the quality of $\mathrm{CD}^{+} \mathrm{T}$ cell memory development and recall responses (58-61). It is likely that costimulation confounds studies of the individual contributions of either IL-2 or IL-15 $(45,62,63)$. Costimulation provides a set of redundant activation signals that may obscure the unique contribution of either IL-2 or IL-15 in recall in studies utilizing IL-2/IL-2R $\alpha$ or IL-15/ IL-15R $\alpha$ mice $(42,63)$. In our studies, the use of CoB revealed distinct roles for IL-2R compared with IL-15R. The high-affinity IL-2R was dispensable for effective memory $C D 8^{+} \mathrm{T}$ cell recall responses, whereas blockade of CD122, which interrupts both IL-2R and IL-15R, abrogated memory $\mathrm{CD}^{+} \mathrm{T}$ cell-dependent graft rejection. The source and sequence of events leading to IL-15R-mediated costimulation-independent recall responses in graft rejection requires further investigation.

Targeting CD122 provides the opportunity to block 2 distinct pathways that support $\mathrm{T}$ cell responses with a single reagent. Both allograft rejection and autoimmune disease are characterized by naive and memory $\mathrm{T}$ cell recruitment into a pathogenic response, thus there is a need to address both primary and recall responses in order to ameliorate disease. Previous studies have underscored the potential of the IL-15 pathway to mediate autoimmune disease and allograft rejection. Interruption of IL-15 signaling alleviated autoimmunity and prevented islet allograft rejection (21, 64-68). Current, clinically approved therapeutics in transplantation are designed to solely interrupt the high-affinity IL-2R in order to promote allograft acceptance $(46,47)$. Our data suggest that targeting both the IL-2 and IL-15 pathways with a single agent, anti-CD122, may be a superior strategy for limiting pathogenic $\mathrm{T}$ cell responses.

Beyond its role as a signaling receptor subunit for both IL-2 and IL-15, recent studies have identified CD122 expression as a marker of stem cell memory $\mathrm{T}$ cells $\left(\mathrm{T}_{\mathrm{SCM}}\right)(69-71)$. These cells have superior proliferative capacity compared with conventional $\mathrm{T}_{\mathrm{CM}}$ or $\mathrm{T}_{\mathrm{EM}}$ and in a model of graft-versus-host disease these cells required CD28 and IL-15 signaling (72). Studies aimed at assess- 

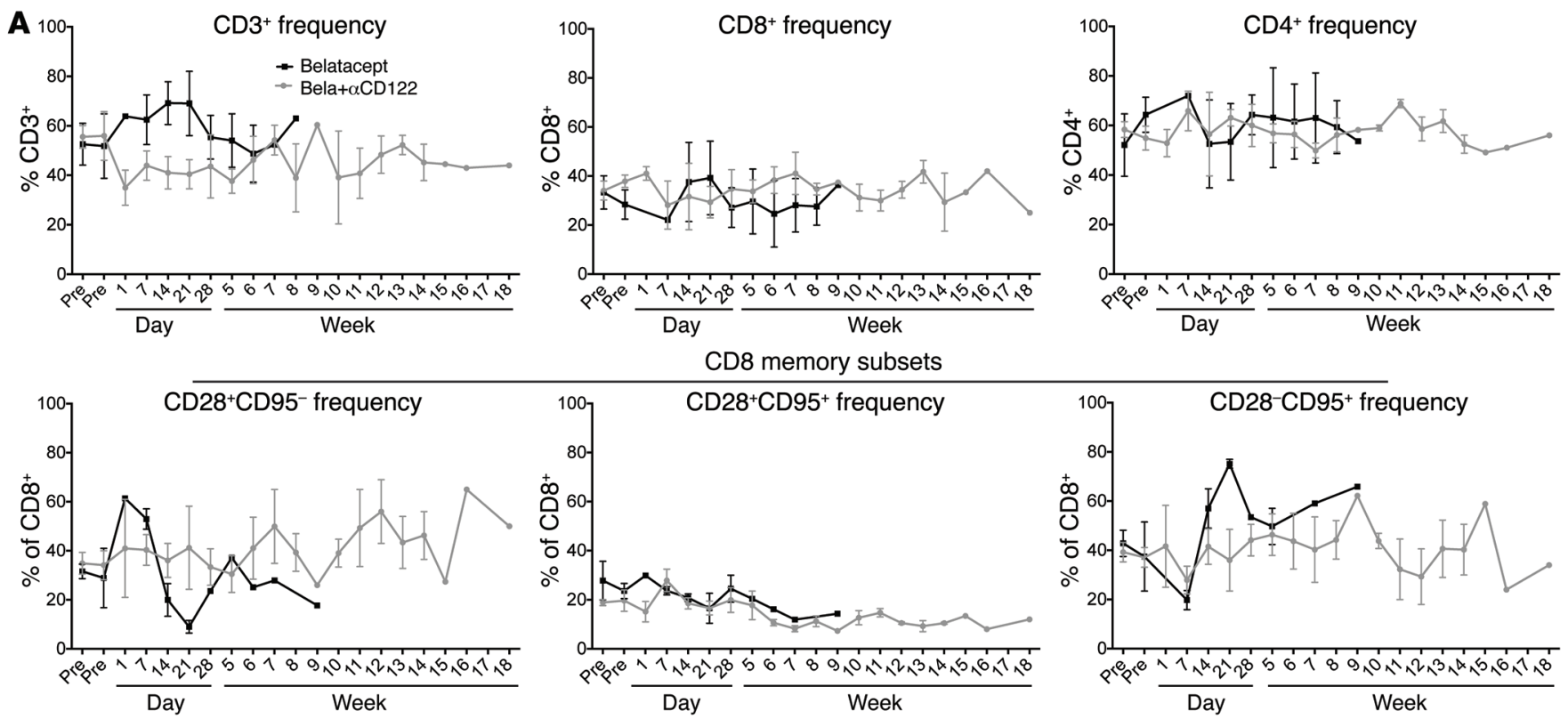

B

\begin{tabular}{|l|l|l|}
\hline Therapy & ID & Survival \\
\hline Belatacept & B1 & Day 8 \\
& B2 & Day 12 \\
& B3 & Day 29 \\
& B4 & Day 47 \\
& B5 & Day 53 \\
\hline Belatacept & C1 & Day 35 \\
+aCD122 & C2 & Day 67 \\
\cline { 2 - 3 } & C3 & Day 138 \\
\cline { 2 - 3 } & C4 & Day 177 \\
& C5 & Day 218 \\
\hline
\end{tabular}
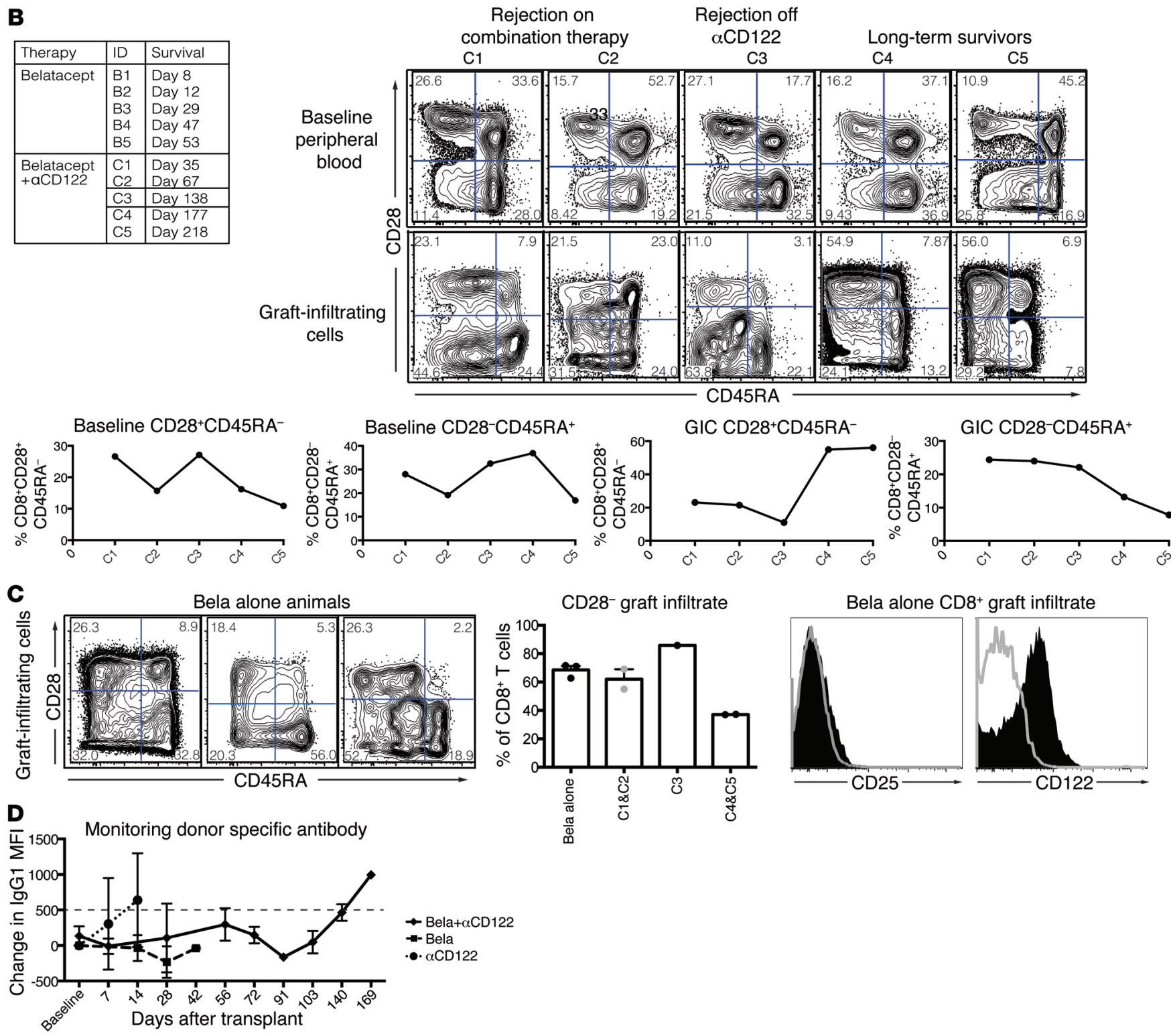

CD28- graft infiltrate

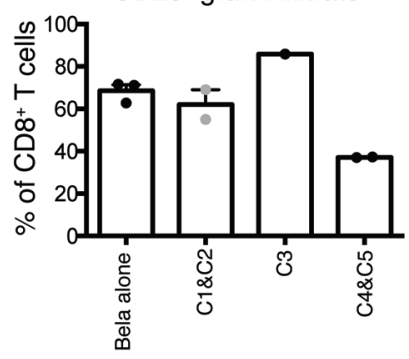

Bela alone $\mathrm{CD}^{+}$graft infiltrate

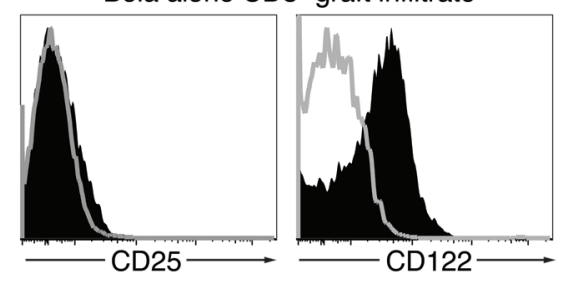


Figure 7. Immunologic impact of combined belatacept+aCD122 therapy in NHP kidney transplant recipients. (A) Longitudinal analysis of $\mathrm{CD}^{+} \mathrm{T}$ cell frequencies did not reveal significant differences in $\mathrm{CD} 4^{+}$or $\mathrm{CD} 8^{+}$subsets, nor were there significant changes in memory subsets between belatacept (black squares) and belatacept $+\alpha C D 122$ (gray circles) treated animals. (B) Comparison of pretransplant $\mathrm{CD} 8^{+}$memory subsets did not discriminate between animals which rejected on combination therapy ( $\mathrm{C} 1$ and $\mathrm{C} 2$ ) versus those which rejected after withdrawal of anti-CD122 (C3) versus animals with prolonged survival ( $C 4$ and $C 5)$. However, graft infiltrating $C D 8^{+} T$ cells in animals which experienced prolonged survival demonstrated a marked increase in CD28+CD45RA- T cells. Data represented by FACS plots and corresponding graphs depicting memory subset frequencies. (C) Characterization of graft infiltrate from 3 animals treated with belatacept alone demonstrating similar graft infiltrate phenotype to $C 1$ and $C 2$, combination therapy-resistant animals. Sample FACS plot of one belatacept alone animal demonstrating no increased expression of CD25 in graft infiltrating $\mathrm{CD}^{+} \mathrm{T}$ cells (solid black histogram) compared with peripheral blood (gray histogram, no fill) at the time of rejection. In contrast graft infiltrating CD8 ${ }^{+} \mathrm{T}$ cells (solid black histogram) had increased expression of CD122. (D) Combination belatacept $+\alpha \mathrm{CD} 122$ (black diamonds) and belatacept monotherapy (black squares) treated animals did not develop donor-specific antibody during treatment. Animals receiving $\alpha$ CD122 monotherapy (black circles) demonstrated a positive DSA at the time of sacrifice. DSA greater than $500 \mathrm{MFI}$ was positive.

ing the role of $\mathrm{T}_{\mathrm{SCM}}$ in alloimmunity and autoimmunity, and the role of CD122 as a phenotypic or functional marker, may aid in the development of therapeutic strategies. Others have defined a role for $\mathrm{CD} 122^{+} \mathrm{CD} 8^{+} \mathrm{T}$ cells as a potent regulator of the immune response $(73,74)$. In both mice and NHPs, we found that the addition of CD122 blockade prolonged allograft survival. Current, clinically approved CD25-directed therapy is thought to have a detrimental impact on conventional Tregs, which support allograft tolerance. Adoption of a strategy that targets CD122 rather than $\mathrm{CD} 25$ may spare $\mathrm{CD} 4^{+} \mathrm{CD} 25^{+}$Tregs, as we found that addition of CD122 blockade may lead to increased intragraft Tregs. The physiologic impact of $\mathrm{CD} 122^{+} \mathrm{CD} 8^{+}$regulatory $\mathrm{T}$ cells, and any potential detrimental impact of CD122-directed therapy on this tolerogenic subset, warrant further study.

In this report we outline a new strategy for the optimization of clinical $\mathrm{CoB}$, built on a finer mechanistic understanding of the role of IL-2R and IL-15R. We translated these findings from the murine to NHP model of kidney transplantation utilizing a humanized antibody directed at CD122. Costimulation-independent responses highlight the unique role of IL-2 and IL-15, and together with emerging data regarding the capacity of IL-15 to uniquely support costimulation-independent responses of human memory $\mathrm{CD} 8^{+}$ $\mathrm{T}$ cells, these studies provide the basis to explore potential future clinical translation (29).

\section{Methods}

Mice

C57BL/6 $\left(\mathrm{H}-2^{\mathrm{b}}\right)$ and $\mathrm{BALB} / \mathrm{c}\left(\mathrm{H}-2^{\mathrm{d}}\right)$ mice were obtained from the National Cancer Institute (Frederick, MD). OT-I (75) transgenic mice, purchased from Taconic Farms, were bred to Thy1.1 $1^{+}$background at Emory University. mOVA mice (C57BL/6 background, $\mathrm{H}-2^{\mathrm{b}}$ ) (76) were purchased from The Jackson Laboratory. All animals were maintained in accordance with Emory University IACUC guidelines. All animals were housed in pathogen-free animal facilities at Emory University.

\section{Viral infection and kinetic analysis}

To induce acute infection, mice were inoculated with $2 \times 10^{5} \mathrm{PFU}$ LCMV acute Armstrong strain (i.p. injection). Virus-specific CD8 ${ }^{+} \mathrm{T}$ cells were monitored with APC-conjugated gp33-41 tetramer.

\section{Donor-reactive T cell adoptive transfers and memory generation}

To generate OVA-specific memory T cells, splenocytes from Thy $1.1^{+}$ OT-I mice were resuspended in PBS and $1.0 \times 10^{4}$ Thy1.1 $1^{+}$OT-I T cells were injected i.v. 24-48 hours prior to inoculation with $10^{4} \mathrm{CFU}$ Lm.OVA (77) by i.p. injection. After 30 days, peripheral frequencies of Thy1.1 OT-I T cells were assessed and mice were given recall challenge with OVA-expressing skin graft from mOVA donors.

\section{Skin transplantation and antibody treatment}

Full-thickness tail or ear skin was transplanted onto the dorsal thorax of recipient mice and secured with adhesive bandages. Where indicated, mice were treated with $250 \mu \mathrm{g}$ CTLA4-Ig (Bristol Myers Squibb), 250 $\mu \mathrm{g}$ hamster monoclonal anti-mouse CD154 (MR-1, BioXcell), $200 \mu \mathrm{g}$ anti-CD122 (ChMBC7, JN Biosciences), or $200 \mu \mathrm{g}$ anti-CD25 (PC61, BioXcell) i.p. on days 0, 2, 4, and 6 after transplantation. ChMBC7 is available from JN Biosciences via material transfer agreement.

\section{Acute graft-versus-host disease model}

C57BL/6 splenocytes were labeled with $10 \mu \mathrm{M}$ Cell Trace Violet (CTV, C34571, Invitrogen). C57BL/6 CTV-labeled splenocytes $\left(3 \times 10^{7}\right)$ were transferred i.v. into sublethally irradiated (800 rads) BALB/c recipients, and selected groups received therapy on days 0 and 2 as described above. Splenocytes were harvested on day 3 and analyzed by flow cytometry to assess CTV-labeled cell division. Experiments involved 3-5 mice per group, and were verified in 3 independent repeats.

\section{Donor-recipient pair selection and kidney transplantation}

All experiments described herein were performed in compliance with the principles set forth in the Guide for the Care and Use of Laboratory Animals (Institute of Laboratory Animal Resources, National Research Council, DHHS). Outbred rhesus monkeys (Macaca mulatta) ranging between 3 and 5 years old were obtained from AlphaGenesis, Inc., and Yerkes National Primate Research Center. Donor-recipient pairs were chosen to maximize genetic disparity at both MHC class I and class II alleles based on 454 deep-sequencing analysis (University of Wisconsin, Madison, WI). Animals were heparinized (100 U/kg) during organ procurement and implantation. Left native nephrectomy was performed at least 3 weeks prior to transplantation, and a completion right native nephrectomy was performed at the time of transplantation. All transplanted animals were monitored with daily clinical assessment and serial laboratory evaluations, including complete blood count and serum chemistry. Animals demonstrated excellent graft function postoperatively and were sacrificed at the time of allograft rejection, defined by graft dysfunction. Depressed renal function pursuant to allograft rejection was determined by 2 consecutive measurements of Cr greater than 5 or BUN greater than 120 .

\section{NHP experimental groups and immunomodulation}

Rhesus macaques underwent bilateral nephrectomy and life-sustaining renal allograft transplantation. All donor-recipient pairs were MHC defined and maximally mismatched. Five animals received belatacept (Bristol Myers Squibb) as follows: do, $10 \mathrm{mg} / \mathrm{kg}$; d4, $15 \mathrm{mg}$ / 
A

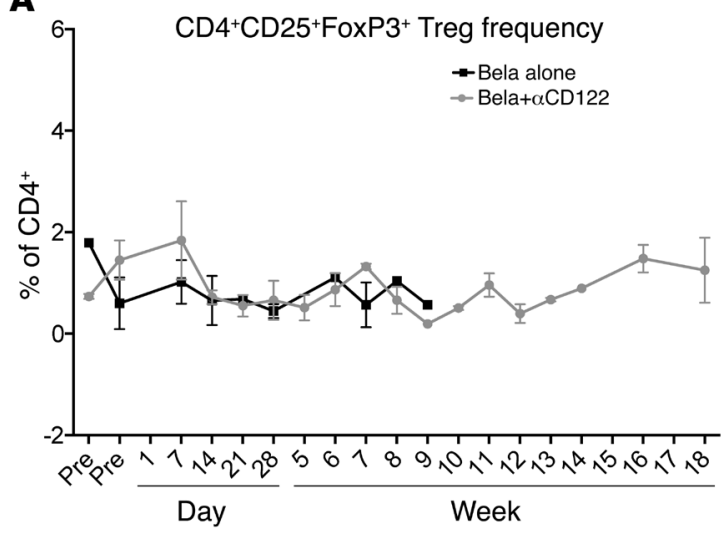

B Graft-infiltrating

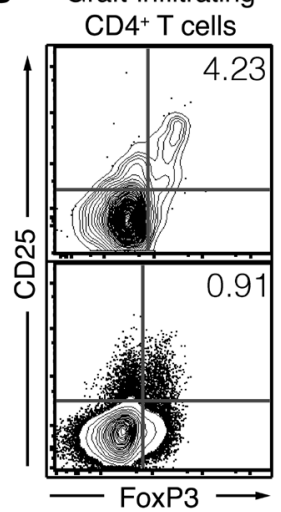

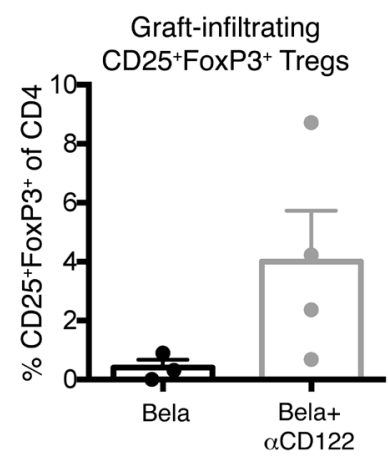

Figure 8. Increased graft infiltrating Tregs in combination belatacept+ $\alpha$ CD122. (A) Longitudinal analysis of Tregs in the peripheral blood of animals treated with belatacept monotherapy (black squares) compared with belatacept $+\alpha C D 122$ (gray circles) revealed no significant differences between the treatment groups. (B) Sample FACS plot of combination belatacept+aCD122 (top) treated animal compared with belatacept monotherapy (bottom). Graphical representation demonstrating a trend toward increased graft infiltrating Tregs in combination bela $+\alpha \mathrm{CD} 122$ (gray circles, mean $\pm \mathrm{SEM}, 4.001 \% \pm 1.732 \%$ ) compared with belatacept monotherapy (black circles, $0.4043 \% \pm 0.2462 \%, P=0.1414$, Student's $t$ test).

$\mathrm{kg} ; \mathrm{d} 14-\mathrm{d} 28,20 \mathrm{mg} / \mathrm{kg}$ weekly; d42, $20 \mathrm{mg} / \mathrm{kg} ; \mathrm{d} 56,20 \mathrm{mg} / \mathrm{kg} ; \mathrm{d} 84$, $20 \mathrm{mg} / \mathrm{kg} ; \mathrm{d} 112,20 \mathrm{mg} / \mathrm{kg} ; \mathrm{d} 140,20 \mathrm{mg} / \mathrm{kg}$. Two animals received $5 \mathrm{mg} / \mathrm{kg}$ anti-CD122 alone (HuABC2, JN Biosciences) on d0, d4, d7, $\mathrm{d} 14, \mathrm{~d} 21, \mathrm{~d} 28, \mathrm{~d} 42$, d56, and d70. HuABC2 is available from JN Biosciences via material transfer agreement. Five animals received combination belatacept and anti-CD122 as described (Figure 6C).

\section{Antibodies and flow cytometric analysis}

Nonhuman primates. Flow cytometric analysis was performed up to 3 times before transplantation and serially after transplantation to characterize peripheral blood immune cell phenotypes. Total $\mathrm{T}$ cells and $\mathrm{T}$ cell subsets were quantified by complete blood cell count and flow cytometry. Fresh PBMCs were isolated by Ficoll density gradient centrifugation (BD Biosciences). PBMCs were stained with the following mAbs: CD3 PacBlue, CD95 V450, CD3 Alexa 700, CD4 PerCP-Cy5.5, CD8 V500, CD28 PE-Cy7, CD25 PE-Cy7, IFN- $\gamma$ PE-Cy7, CD28 APC, TNF APC, CD122 (both clones Mik2 and Mik $\beta 3$ ) (all from BD Biosciences). PE human IgG1 isotype control clone QA16A12 was utilized to define CD122 expression in Figure 5 (Biolegend). PBMCs $\left(1.5 \times 10^{6}\right)$ were incubated with appropriately titered antibodies for 15 minutes at $4^{\circ} \mathrm{C}$ and washed twice. For intracellular staining, cells were fixed and permeabilized using the BD Cytofix/Cytoperm kit (BD Biosciences) according to the manufacturer's instructions. Intracellular staining was performed with FoxP3 V450 (Biolegend) to detect Tregs. Samples were acquired immediately on a BD LSR II multicolor flow cytometer (BD Biosciences) and data were analyzed using FlowJo software (Tree Star). For mixed lymphocyte reactions, $1 \times 10^{6} \mathrm{PBMCs}$ were labeled with CFSE labeling dye, and incubated with CTV-labeled and irradiated MHC mismatched stimulator PBMCs $\left(1 \times 10^{6}\right)$. For the stimulation assay, $1.5 \times 10^{6}$ PBMCs were cultured in RPMI 1640 (Corning Cellgro) supplemented with $10 \%$ fetal bovine serum and stimulated with $10 \mu \mathrm{M}$ phorbol 12-myristate 13-acetate (PMA) and $200 \mathrm{nM}$ ionomycin (SigmaAldrich) for 5 hours. IL-2 (100 ng/ml) and/or IL-15 (10 ng/ml) were utilized in both 4-5 hour stimulations (Figure 5) and in mixed lymphocyte reaction (MLR) (Figure 6) as described (Peprotech). PBMCs were washed twice prior to antibody staining and data acquisition.

\section{Murine}

Surface stains and flow cytometry. Spleens or draining axillary and brachial LNs were stained for CD4, CD8, Thy1.1, CTLA4, PD-1, KLRG1, CD127, CD62L, CD122 (clone 5H4, different regional binding site than ChMBC7), and CD44 (Biolegend). Samples were analyzed using an LSRII FACS machine (BD Biosciences). Data were analyzed using FlowJo software (Treestar).

Intracellular cytokine staining. Where indicated, responder lymphocytes or splenocytes were stimulated with PMA/ionomycin or $10 \mathrm{nM}$ OVA257-264 (Genscript) in the presence of $10 \mu \mathrm{g} / \mathrm{ml} \mathrm{Brefel-}$ din A for 4-5 hours. An intracellular staining kit was used to detect TNF, IFN- $\gamma$ (Biolegend), and IL-2 (BD Biosciences) according to manufacturer's instructions.

\section{Statistics}

Survival statistics were calculated using a log-rank test. T cell frequencies, absolute numbers, and MFI were compared using 1-way ANOVA with Tukey's multiple comparisons test, or unpaired $t$ test (comparison between 2 groups). Data were analyzed using Prism 6 (GraphPad Software). $P<0.05$ was considered statistically significant.

\section{Study approval}

Both murine and NHP experimental subjects received humane care and treatment in accordance with Emory University IACUC guidelines, and all experimental protocols utilizing animals were conducted with approval by Emory University's institutional review board.

\section{Author contributions}

DVM and ABA designed the study and experiments. DVM conducted the murine infection and skin graft experiments, primate experiments, and data analysis, and wrote the manuscript. YD helped with murine skin graft experiments. DVM, ABA, LBH, and SCK performed primate kidney transplants. CPB assisted with primate flow cytometry. JYT developed murine and humanized antiCD122 mAbs. EAS and JJ provided veterinary care and supervision of primate experiments. CPL provided help with experimental 
design. ABA conceived of many experiments, assisted with analysis, and helped write the manuscript.

\section{Acknowledgments}

DVM was supported by the NIH Ruth L. Kirschstein National Research Service Award Individual Predoctoral MD/PhD Fellowship (F30 DK109665). The primate experiments were also supported by the National Institute for Allergy and Infectious Diseases Nonhuman
Primate Transplantation Tolerance Cooperative Study Group grant AI051731 from NIH. Primate experiments were also supported by the Yerkes National Primate Research Center base grant RR00165.

Address correspondence to: Andrew B. Adams, Woodruff Memorial Research Building, Suite 5105 WMB, 101 Woodruff Circle, Atlanta Ga 30322 USA. Phone: 404.712.8424; Email: andrew.b.adams@emory.edu.
1. Larsen CP, et al. Rational development of LEA29Y (belatacept), a high-affinity variant of CTLA4-Ig with potent immunosuppressive properties. Am J Transplant. 2005;5(3):443-453.

2. Vincenti F, et al. Costimulation blockade with belatacept in renal transplantation. NEngl J Med. 2005;353(8):770-781.

3. Vanrenterghem Y, et al. Belatacept-based regimens are associated with improved cardiovascular and metabolic risk factors compared with cyclosporine in kidney transplant recipients (BENEFIT and BENEFIT-EXT studies). Transplantation. 2011;91(9):976-983.

4. Rostaing L, et al. Long-term belatacept exposure maintains efficacy and safety at 5 years: results from the long-term extension of the BENEFIT study. Am J Transplant. 2013;13(11):2875-2883.

5 . Vincenti F, et al. Belatacept and long-term outcomes in kidney transplantation. $N$ Engl J Med. 2016;374(4):333-343.

6 . Vincenti F, et al. A phase III study of belataceptbased immunosuppression regimens versus cyclosporine in renal transplant recipients (BENEFIT study). Am J Transplant. 2010;10(3):535-546.

7. Adams AB, et al. Belatacept combined with transient calcineurin inhibitor therapy prevents rejection and promotes improved long-term renal allograft function. Am J Transplant. 2017;17(11):2922-2936.

8. Bingaman AW, Farber DL. Memory T cells in transplantation: generation, function, and potential role in rejection. Am J Transplant. 2004;4(6):846-852.

9. Adams AB, et al. Heterologous immunity provides a potent barrier to transplantation tolerance. J Clin Invest. 2003;111(12):1887-1895.

10. Floyd TL, et al. Limiting the amount and duration of antigen exposure during priming increases memory $\mathrm{T}$ cell requirement for costimulation during recall. JImmunol. 2011;186(4):2033-2041.

11. Trambley J, et al. Asialo $\mathrm{GM} 1^{+} \mathrm{CD} 8^{+} \mathrm{T}$ cells play a critical role in costimulation blockaderesistant allograft rejection. J Clin Invest . 1999;104(12):1715-1722.

12. Mathews DV, et al. Belatacept-resistant rejection is associated with CD28+ memory CD8 T cells. Am J Transplant. 2017;17(9):2285-2299.

13. Cortes-Cerisuelo $\mathrm{M}$, et al. Increased pretransplant frequency of CD28+CD4+ TEM predicts Belatacept-resistant rejection in human renal transplant recipients. Am J Transplant. 2017;17(9):2350-2362.

14. Appay V, van Lier RA, Sallusto F, Roederer M. Phenotype and function of human T lymphocyte subsets: consensus and issues. Cytometry $A$. 2008;73(11):975-983.
15. Mahnke YD, Brodie TM, Sallusto F, Roederer M, Lugli E. The who's who of T-cell differentiation: human memory T-cell subsets. Eur J Immunol. 2013;43(11):2797-2809.

16. Ikemizu S, Chirifu M, Davis SJ. IL-2 and IL-15 signaling complexes: different but the same. Nat Immunol. 2012;13(12):1141-1142.

17. Sadlack B, Kühn R, Schorle H, Rajewsky K, Müller W, Horak I. Development and proliferation of lymphocytes in mice deficient for both interleukins-2 and -4. Eur J Immunol. 1994;24(1):281-284.

18. Lodolce JP, et al. IL-15 receptor maintains lymphoid homeostasis by supporting lymphocyte homing and proliferation. Immunity. 1998;9(5):669-676.

19. Kennedy MK, et al. Reversible defects in natural killer and memory CD8 T cell lineages in interleukin 15-deficient mice. J Exp Med. 2000;191(5):771-780.

20. Sadlack B, Merz H, Schorle H, Schimpl A, Feller AC, Horak I. Ulcerative colitis-like disease in mice with a disrupted interleukin-2 gene. Cell. 1993;75(2):253-261.

21. Yokoyama S, et al. Antibody-mediated blockade of IL-15 reverses the autoimmune intestinal damage in transgenic mice that overexpress IL-15 in enterocytes. Proc Natl Acad Sci US A. 2009;106(37):15849-15854.

22. Becker TC, et al. Interleukin 15 is required for proliferative renewal of virus-specific memory CD8 T cells. J Exp Med. 2002;195(12):1541-1548.

23. Judge AD, Zhang X, Fujii H, Surh CD, Sprent J. Interleukin 15 controls both proliferation and survival of a subset of memory-phenotype CD8(+) T cells. JExp Med. 2002;196(7):935-946.

24. Surh CD, Sprent J. Homeostasis of naive and memory T cells. Immunity. 2008;29(6):848-862.

25. Sneller MC, et al. IL-15 administered by continuous infusion to rhesus macaques induces massive expansion of CD8+ T effector memory population in peripheral blood. Blood. 2011;118(26):6845-6848.

26. Richer MJ, Pewe LL, Hancox LS, Hartwig SM, Varga SM, Harty JT. Inflammatory IL-15 is required for optimal memory $\mathrm{T}$ cell responses. J Clin Invest. 2015;125(9):3477-3490.

27. Chiu WK, Fann M, Weng NP. Generation and growth of CD28nullCD8+ memory T cells mediated by IL-15 and its induced cytokines. J Immunol. 2006;177(11):7802-7810.

28. Miyagawa F, et al. IL-15 serves as a costimulator in determining the activity of autoreactive CD8 T cells in an experimental mouse model of graft-versus-host-like disease. J Immunol. 2008;181(2):1109-1119.

29. Traitanon O, et al. IL-15 induces alloreactive
CD28(-) memory CD8 T cell proliferation and CTLA4-Ig resistant memory CD8 T cell activation. Am J Transplant. 2014;14(6):1277-1289.

30. Bluestone JA, et al. The effect of costimulatory and interleukin 2 receptor blockade on regulatory T cells in renal transplantation. Am J Transplant. 2008;8(10):2086-2096.

31. Waldmann TA. The biology of interleukin-2 and interleukin-15: implications for cancer therapy and vaccine design. Nat Rev Immunol. 2006;6(8):595-601.

32. Ku CC, Murakami M, Sakamoto A, Kappler J, Marrack P. Control of homeostasis of CD8+ memory T cells by opposing cytokines. Science. 2000;288(5466):675-678.

33. Kaplan B. Belatacept: the promises and challenges of belatacept and costimulatory blockade. Am J Transplant. 2010;10(3):441-442.

34. Valujskikh A, Lakkis FG. In remembrance of things past: memory T cells and transplant rejection. Immunol Rev. 2003;196:65-74.

35. Ford ML, Larsen CP. Transplantation tolerance: memories that haunt us. Sci Transl Med. 2011;3(86):86ps22.

36. Brook MO, Wood KJ, Jones ND. The impact of memory $\mathrm{T}$ cells on rejection and the induction of tolerance. Transplantation. 2006;82(1):1-9.

37. Valujskikh A, Pantenburg B, Heeger PS. Primed allospecific $\mathrm{T}$ cells prevent the effects of costimulatory blockade on prolonged cardiac allograft survival in mice. Am J Transplant. 2002;2(6):501-509.

38. Croft M, Bradley LM, Swain SL. Naive versus memory CD4 T cell response to antigen. Memory cells are less dependent on accessory cell costimulation and can respond to many antigen-presenting cell types including resting $\mathrm{B}$ cells. J Immunol. 1994;152(6):2675-2685.

39. Goldrath AW, et al. Cytokine requirements for acute and Basal homeostatic proliferation of naive and memory CD8+ T cells. J Exp Med. 2002;195(12):1515-1522.

40. Tan JT, Ernst B, Kieper WC, LeRoy E, Sprent J, Surh CD. Interleukin (IL)-15 and IL-7 jointly regulate homeostatic proliferation of memory phenotype CD8+ cells but are not required for memory phenotype CD4+ cells. J Exp Med. 2002;195(12):1523-1532.

41. Mitchell DM, Ravkov EV, Williams MA. Distinct roles for IL-2 and IL-15 in the differentiation and survival of CD8+ effector and memory T cells. Jimmunol. 2010;184(12):6719-6730.

42. Mathieu C, et al. IL-2 and IL-15 regulate CD8+ memory T-cell differentiation but are dispensable for protective recall responses. Eur J Immunol. 2015;45(12):3324-3338.

43. Schluns KS, Williams K, Ma A, Zheng XX, 
Lefrançois L. Cutting edge: requirement for IL-15 in the generation of primary and memory antigen-specific CD8 T cells. JImmunol. 2002;168(10):4827-4831.

44. Bevan MJ. Helping the CD8(+) T-cell response. Nat Rev Immunol. 2004;4(8):595-602.

45. Hernandez MG, Shen L, Rock KL. CD40 on APCs is needed for optimal programming, maintenance, and recall of CD8+ T cell memory even in the absence of $\mathrm{CD} 4+\mathrm{T}$ cell help. J Immunol. 2008;180(7):4382-4390.

46. Nashan B, Moore R, Amlot P, Schmidt AG, Abeywickrama K, Soulillou JP. Randomised trial of basiliximab versus placebo for control of acute cellular rejection in renal allograft recipients. CHIB 201 International Study Group. Lancet. 1997;350(9086):1193-1198.

47. Vincenti F, et al. Interleukin-2-receptor blockade with daclizumab to prevent acute rejection in renal transplantation. Daclizumab Triple Therapy Study Group. N Engl J Med.1998;338(3):161-165.

48. Jones TR, et al. The role of the IL-2 pathway in costimulation blockade-resistant rejection of allografts. J Immunol. 2002;168(3):1123-1130.

49. Lamb KE, Lodhi S, Meier-Kriesche HU. Longterm renal allograft survival in the United States: a critical reappraisal. Am J Transplant. 2011;11(3):450-462.

50. Ring AM, et al. Mechanistic and structural insight into the functional dichotomy between IL-2 and IL-15. Nat Immunol. 2012;13(12):1187-1195.

51. Sadlack B, et al. Generalized autoimmune disease in interleukin-2-deficient mice is triggered by an uncontrolled activation and proliferation of $\mathrm{CD} 4+$ T cells. Eur JImmunol. 1995;25(11):3053-3059.

52. Malek TR, Castro I. Interleukin-2 receptor signaling: at the interface between tolerance and immunity. Immunity. 2010;33(2):153-165.

53. Giron-Michel J, et al. Interleukin-15 plays a central role in human kidney physiology and cancer through the $\gamma c$ signaling pathway. PLOS ONE. 2012;7(2):e31624.

54. Chirifu M, et al. Crystal structure of the IL-15-IL-15Ralpha complex, a cytokinereceptor unit presented in trans. Nat Immunol. 2007;8(9):1001-1007.

55. Williams MA, Tyznik AJ, Bevan MJ. Interleukin-2 signals during priming are required for second- ary expansion of CD8+ memory T cells. Nature. 2006;441(7095):890-893.

56. Obar JJ, et al. CD4+ T cell regulation of CD25 expression controls development of shortlived effector CD8+ $\mathrm{T}$ cells in primary and secondary responses. Proc Natl Acad Sci U S A. 2010;107(1):193-198.

57. Sandau MM, Kohlmeier JE, Woodland DL, Jameson SC. IL-15 regulates both quantitative and qualitative features of the memory CD8 T cell pool. J Immunol. 2010;184(1):35-44.

58. Castro I, Yu A, Dee MJ, Malek TR. The basis of distinctive IL-2- and IL-15-dependent signaling: weak CD122-dependent signaling favors CD8+ T central-memory cell survival but not T effector-memory cell development. JImmunol. 2011;187(10):5170-5182.

59. Kalia V, Sarkar S, Subramaniam S, Haining WN, Smith KA, Ahmed R. Prolonged interleukin-2Ralpha expression on virus-specific CD8+ $\mathrm{T}$ cells favors terminal-effector differentiation in vivo. Immunity. 2010;32(1):91-103.

60. Castro I, Dee MJ, Malek TR. Transient enhanced IL-2R signaling early during priming rapidly amplifies development of functional CD8+ T effector-memory cells. JImmunol. 2012;189(9):4321-4330.

61. Pipkin ME, Sacks JA, Cruz-Guilloty F, Lichtenheld MG, Bevan MJ, Rao A. Interleukin-2 and inflammation induce distinct transcriptional programs that promote the differentiation of effector cytolytic T cells. Immunity. 2010;32(1):79-90.

62. Welten SP, et al. The viral context instructs the redundancy of costimulatory pathways in driving CD8(+) T cell expansion. Elife. 2015;4:e07846.

63. Fuse S, Zhang W, Usherwood EJ. Control of memory CD $8+\mathrm{T}$ cell differentiation by CD80/ CD86-CD28 costimulation and restoration by IL-2 during the recall response. J Immunol. 2008;180(2):1148-1157.

64. Chen J, et al. Insulin-dependent diabetes induced by pancreatic beta cell expression of IL-15 and IL-15R $\alpha$. Proc Natl Acad Sci U S A. 2013;110(33):13534-13539.

65. Ferrari-Lacraz S, et al. Targeting IL-15 receptor-bearing cells with an antagonist mutant IL-15/Fc protein prevents disease development and progression in murine collagen-induced arthritis. JImmunol. 2004;173(9):5818-5826.

66. Ferrari-Lacraz S, Zheng XX, Fueyo AS, Maslinski W, Moll T, Strom TB. CD8(+) T cells resistant to costimulatory blockade are controlled by an antagonist interleukin-15/Fc protein. Transplantation. 2006;82(11):1510-1517.

67. Ferrari-Lacraz S, et al. An antagonist IL-15/Fc protein prevents costimulation blockade-resistant rejection. J Immunol. 2001;167(6):3478-3485.

68. Ferrari-Lacraz S, Zheng XX, Kim YS, Maslinski W, Strom TB. Addition of an IL-15 mutant/FCgamma2A antagonist protein protects islet allografts from rejection overriding costimulation blockade. Transplant Proc. 2002;34(3):745-747.

69. Lugli E, et al. Superior T memory stem cell persistence supports long-lived T cell memory. JClin Invest. 2013;123(2):594-599.

70. Gattinoni L, Klebanoff CA, Restifo NP. Paths to stemness: building the ultimate antitumour $\mathrm{T}$ cell. Nat Rev Cancer. 2012;12(10):671-684.

71. Flynn JK, Gorry PR. Stem memory T cells (TSCM)-their role in cancer and HIV immunotherapies. Clin Transl Immunology. 2014;3(7):e20.

72. Cieri N, et al. IL-7 and IL-15 instruct the generation of human memory stem $\mathrm{T}$ cells from naive precursors. Blood. 2013;121(4):573-584.

73. Dai H, Wan N, Zhang S, Moore Y, Wan F, Dai Z. Cutting edge: programmed death-1 defines $\mathrm{CD} 8+\mathrm{CD} 122+\mathrm{T}$ cells as regulatory versus memory T cells. J Immunol. 2010;185(2):803-807.

74. Dai Z, et al. Natural CD8+CD122+ T cells are more potent in suppression of allograft rejection than CD4+CD25+ regulatory T cells. Am J Transplant. 2014;14(1):39-48.

75. Hogquist KA, Gavin MA, Bevan MJ. Positive selection of $\mathrm{CD} 8+\mathrm{T}$ cells induced by major histocompatibility complex binding peptides in fetal thymic organ culture. JExp Med. 1993;177(5):1469-1473.

76. Ehst BD, Ingulli E, Jenkins MK. Development of a novel transgenic mouse for the study of interactions between $\mathrm{CD} 4$ and $\mathrm{CD} 8 \mathrm{~T}$ cells during graft rejection. Am J Transplant. 2003;3(11):1355-1362.

77. Shen H, Miller JF, Fan X, Kolwyck D, Ahmed R, Harty JT. Compartmentalization of bacterial antigens: differential effects on priming of CD8 T cells and protective immunity. Cell. 1998;92(4):535-545. 